\title{
PUBLICACIONES SOBRE FILOLOGÍA GRIEGA EN ESPAÑA (2018)
}

\author{
Helena Rodríguez Somolinos \\ ILC - CSIC. Madrid \\ helena.rsomolinos@cchs.csic.es
}

\section{RESUMEN}

Bibliografía relativa a Filología Griega publicada en España en 2018.

PAlabras Clave: Filología Griega; Bibliografía: España

\section{Abstract}

Bibliography concerning Greek Philology published in Spain in 2018.

KEY WORDS: Greek Philology; Bibliography: Spain 


\section{ÍNDICE GENERAL}

1. Actas de congresos. Homenajes. Volúmenes colectivos

2. Autores antiguos. Ediciones, traducciones y estudios

3. Historia de la literatura

4. Lingüística griega. Métrica

5. Micenología

6. Epigrafía. Papirología. Numismática

7. Historia de los textos

8. Historia. Cultura. Sociedad

9. Religión. Mitología

10. Cristianismo

11. Filosofía. Ciencia

12. Pervivencia. Humanismo. Historia de la filología

13. Diccionarios. Repertorios. Otros instrumentos

14. Didáctica

\section{REVISTAS}

$A E A$

$A E F$

AFAM

$A M-E$

Antesteria

Arys

$\mathrm{AuOr}$

Bandue

Cal.Ren.
Archivo Español de Arqueología. Madrid, CSIC, Departamento de Arqueología y Prehistoria. http://aespa.revistas.csic.es/index.php/ aespa

Anuario de Estudios Filológicos. Cáceres. Universidad de Extremadura. Facultad de Filosofía y Letras. https://anuariodeestudiosfilologicos.wordpress.com/

Anuari de Filologia. Antiqua et Medievalia. Universitat de Barcelona. Facultat de Filologia. www.raco.cat/index.php/AFAM/index Analecta Malacitana Electrónica. Universidad de Málaga. Facultad de Filosofía y Letras. Sección de Filología. www.anmal.uma.es/

Antesteria. Debates de Historia Antigua. Jóvenes Investigadores del Departamento de Historia Antigua de la Universidad Complutense. https://www.ucm.es/preharq-hantigua/antesteria

Arys. Antigüedad: religiones y sociedades. Madrid. Universidad Carlos III - Asociación Arys. www.uc3m.es/arys

Aula Orientalis. Revista de Estudios del Próximo Oriente Antiguo. Institut Interuniversitari d'Estudis del Pròximo Orient Antic. Sabadell (Barcelona). Editorial Ausa. www.aulaorientalis.org/ Bandue. Revista de la Sociedad Española de Historia de las Religiones. Madrid, Editorial Trotta. http://secr.es/publicaciones/bandue/ Calamus Renascens. Revista de Humanismo y tradición clásica. Alcañiz - Cádiz, Instituto de Estudios Humanísticos, Universidad de Cádiz. www.estudioshumanisticos.org/publicaciones.php 
CCO Collectanea Christiana Orientalia. Universidad de Córdoba. Facultad de Filosofía y Letras. http://www.uco.es/collectanea/

CFCG Cuadernos de Filología Clásica. Estudios Griegos e Indoeuropeos. Universidad Complutense de Madrid. Facultad de Filología. http://revistas.ucm.es/index.php/CFCG

CFCL Cuadernos de Filología Clásica. Estudios Latinos. Universidad Complutense de Madrid. Facultad de Filología. http://revistas.ucm. es/index.php/CFCL

$E B$

Estudios Bíblicos. Madrid. Universidad San Dámaso - Asociación Bíblica Española. http://www.sandamaso.es/publicaciones.php

$E C$

EClás.

Exemplaria Classica. Departamento de Filologías Integradas. Facultad de Humanidades. Universidad de Huelva. www.uhu.es/publicaciones/ojs/index.php/exemplaria/index

$\begin{array}{ll}\text { EH } & \text { Estudios Humanísticos. Filología. Universidad de León. Facultad de } \\ & \text { Filosofía y Letras. http://revpubli.unileon.es/ojs/index.php/EEHHFilo- } \\ & \underline{\text { logia }} \\ & \text { Estudios Interlingüísticos. Asociación de Jóvenes Lingüistas. http:// } \\ & \underline{\text { estudiosinterlinguisticos.com }}\end{array}$

EH Estudios Humanísticos. Filología. Universidad de León. Facultad de

Filosofía y Letras. http://revpubli.unileon.es/ojs/index.php/EEHHFilo-
logia
Estudios Interlingüísticos. Asociación de Jóvenes Lingüistas. http://
estudiosinterlinguisticos.com

Estudios Clásicos. Madrid, Sociedad Española de Estudios Clásicos. http://www.estudiosclasicos.org/estudios-clasicos/

Emerita Emerita. Revista de Lingüística y Filología Clásica. Madrid. C.S.I.C. Instituto de Lenguas y Culturas del Mediterráneo y Oriente Próximo. http://emerita.revistas.csic.es/index.php/emerita

Epos Epos. Revista de Filología. Madrid. Universidad Nacional de Educación a Distancia. Facultad de Filología. http://revistas.uned.es/index.php/EPOS

Faventia Faventia. Universitat Autònoma de Barcelona. Facultat de Lletres. Dpto. de Filología Clásica. http://ddd.uab.es/record/21?ln=ca

FI

Florentia Iliberritana. Revista de Estudios de Antigüedad Clásica. Universidad de Granada. www.ugr.es/ hantigua/florentia.html

$F N$

Fortunatae

Filología Neotestamentaria. Universidad de Córdoba. Facultad de Filosofía y Letras. http://www.bsw.org/filologia-neotestamentaria/ Fortunatae. Revista canaria de filología, cultura y humanidades clásicas. Universidad de la Laguna. Departamento de Filología Clásica y Arabe. http://publica.webs.ull.es/publicaciones/detalle/revista-fortvnatae/fortunatae-revista-canaria-de-filologia-cultura-y-humanidades-clasicas/

Gerión Gerión. Universidad Complutense de Madrid. Departamento de Historia Antigua. http://revistas.ucm.es/index.php/GERI

Habis Habis. Universidad de Sevilla. http://institucional.us.es/habis/

HAnt. Hispania Antiqua. Revista de Historia Antigua. Universidad de Valladolid. Departamento de Historia Antigua.

www.publicaciones.uva.es/Buscador.aspx?txtBusqueda=HISPANIA\%20ANTIQ\&txtFamilia=Humanidades\%20/\%20Revistas 
Helmantica Helmantica. Revista de Filología Clásica y Hebrea. Univ. Pontificia

'Ilu 'Ilu. Revista de Ciencias de las Religiones. Universidad Complutense de Madrid. Instituto Universitario de Ciencias de las Religiones. http://revistas.ucm.es/index.php/ILUR

Ítaca Ítaca. Quaderns Catalans de Cultura Clàsica. Barcelona. Institut d' Estudis Catalans. http://publicacions.iec.cat/PopulaFitxa.do?modu$\underline{\text { leName }=\text { revistes } \text { cientifiques } \& \text { subModuleName }=\& \text { idColleccio }=58}$

Lucentum Lucentum. Anales de la Universidad de Alicante. Prehistoria, Arqueología e Historia antigua. Universidad de Alicante. https://web. ua.es/es/lucentum/

Methodos Methodos. Revista de didàcticadelsestudisclàssics. Paideia. Grup de Didàctica de les Llengües i la Cultura Clàssiques de la Universitat Autònoma de Barcelona. http://pagines.uab.cat/methodos/

MHNH MHNH. Revista internacional de investigación sobre Magia y Astrología antiguas. Málaga, Centro de Ediciones de la Diputación de Málaga. https://www.uma.es/hermes/info/107214/mhnh/

Minerva Minerva. Revista de Filología Clásica. Universidad de Valladolid. Departamento de Filología Clásica. http://minerva.blogs.uva.es/

Myrtia Myrtia. Universidad de Murcia. http://revistas.um.es/myrtia/index

Palaeohispanica Palaeohispanica. Revista sobre lenguas y culturas de la Hispania Antigua. Zaragoza. Institución Fernando el Católico. http://ifc.dpz.es/publicaciones/periodica/id/18

Paremia Paremia. Boletín de Investigaciones Paremiológicas. Madrid. Asociación Cultural Independiente (Sigüenza) - Universidad Complutense. Sersa Ediciones. www.paremia.org/

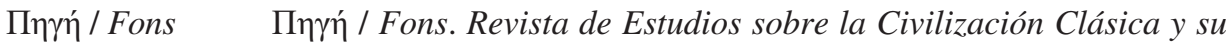
Recepción. Madrid. Instituto de Estudios Clásicos «Lucio Anneo Séneca». Universidad Carlos III de Madrid. https://e-revistas.uc3m. es/index.php/FONS/index

Ph.Canar. Philologica Canariensia. Universidad de Las Palmas de Gran Canaria. Facultad de Filología. http://ojsspdc.ulpgc.es/ojs/index.php/PhilCan/index

Polis Polis. Revista de ideas y formas políticas de la Antigüedad Clásica. Universidad de Alcalá de Henares. http://www1.uah.es/publicaciones/catal.asp

Pyrenae Pyrenae. Revista de Prehistòria i Antiguitat de la Mediterrània Occidental. Barcelona. Universitat de Barcelona. Facultat de Geografia i Història. Departament de Prehistòria, Història Antiga y Arqueologia. www.ub.edu/pyrenae/indexnet.htm

R.S.E.L. Revista Española de Lingüística. Organo de la Sociedad Española de Lingüística. Madrid. www.sel.edu.es/presentacion-revista 
SEBarc.

Sylloge Epigraphica Barcinonensis. Universitat de Barcelona. www.raco.cat/index.php/SEBarc/index

SHHA Studia Historica. Historia Antigua. Universidad de Salamanca. Facultad de Geografía e Historia. Departamento de Prehistoria y arqueología http://revistas.usal.es/index.php/0213-2052/index

SPhV Studia Philologica Valentina. Universidad de Valencia. http://www.uv.es/sphv/

Talia dixit Talia dixit. Revista Interdisciplinar de Retórica e Historiografía. Grupo de Investigación Arenga. Universidad de Extremadura. http://www.eweb.unex.es/eweb/arengas/taliadixit.htm

Tempus Tempus. Revista de actualización científica sobre el Mundo Clásico en España. Madrid, Ediciones Clásicas. https://www.revistatempvs.org/

Thamyris Thamyris. Nova series. Revista de Didáctica de Cultura Clásica. Delegación de Málaga de la S.E.E.C. - Departamentos de Filología Griega y Latina de la Universidad de Málaga. www.thamyris.uma.es

Tycho Tycho. Revista de iniciación en la investigación del teatro clásico grecolatino y su tradición. Universidad de Valencia. www.uv.es/tycho/

Veleia Veleia. Revista de Prehistoria, Historia Antigua, Arqueología y Filología Clásica. Vitoria. Universidad del País Vasco. Instituto de Ciencias de la Antigüedad. http://www.ehu.eus/ojs/index.php/Veleia

Zephyrus Zephyrus. Revista de Prehistoria e Historia Antigua. Universidad de Salamanca.http://campus.usal.es/ revistas trabajo/index.php/0514$\underline{7336}$

\section{ACTAS DE CONGRESOS. HOMENAJES. VOLÚMENES COLECTIVOS}

Classical languages and linguistics:

DE La Villa Polo, J. - Pompei, A. (eds.): Classical languages and linguistics. Lenguas clásicas y lingüística. Madrid, Universidad Autónoma de Madrid, 2018.

Convergencias y divergencias:

Sierra González, Á. (ED.): Convergencias y divergencias (lecturas heterodoxas de filosofía griega). Barcelona, Laertes, 2018.

De nuevo sobre Estrabón:

CASTRo PÁez, E. (ED.): De nuevo sobre Estrabón. Geografía, cartografía, historiografía y tradición. Alcalá de Henares - Sevilla, Universidad de Alcalá de Henares - Universidad de Sevilla, 2018. 
Ecos y resplandores helenos:

Alvarado Teodorika, T. - Grigoriadou,Th. - García Romero, F. (eds.): Ecos y resplandores helenos en la literatura hispana. Siglos XVI-XXI. La Paz, - Madrid, Sociedad Boliviana de Estudios Clásicos - Sociedad Española de Estudios Clásicos, 2018.

\section{L'empremta del mite:}

GREGori, C. - Rosselló, R.-X. (EDS.): L'empremta del mite en la literatura del primer terç del segle XX. Barcelona, Publicacions de l'Abadia de Montserrat, 2018.

\section{Las edades vulnerables:}

Rubiera Cancelas (COORD.): Las edades vulnerables. Infancia y vejez en la Antigüedad. Gijón, Trea, 2018.

Los orígenes del cristianismo en la literatura, el arte y la filosofía:

Álvarez Pedrosa, J. A. et ali (eds.): Los orígenes del cristianismo en la literatura, el arte y la filosofía, II. Madrid, Dykinson, 2018.

Métodos y técnicas en Ciencias de la Antigüedad:

Ortiz de Urbina Álava, E. - Vallejo Ruiz, J.M. (eds.): Métodos y técnicas en Ciencias de la Antigüedad. Estudios sobre investigación y docencia. Anejos de Veleia, Acta 16. Vitoria, Universidad del País Vasco, 2018.

Miscellanea philologica et epigraphica Marco Mayer oblata (= AFAM 8, 2018)

Guzmán Almagro, A. - Velaza, J. (eds.): Miscellanea philologica et epigraphica Marco Mayer oblata $=$ AFAM 8, 2018.

Nardus et myrto plexae coronae:

Valverde Abril, J. - Gatsioufa, P. (EDS.): Nardus et myrto plexae coronae. Symmikta philologica ad amicos in iubilaeo obsequendos. Granada, Universidad, 2018.

\section{Opera selecta:}

Balda Baranda, A. - Redondo Moyano, E. (eds.): Opera selecta. Estudios sobre el mundo clásico. Anejos de Veleia, Acta 15). Vitoria, Universidad del País Vasco, 2018.

\section{Phílos hetaîros:}

Conti, L. - Crespo, E. - Rodríguez Blanco, M.E: - Torrego, E. - de la Villa, J. (eds.): Phílos hetaîros. Homenaje al Profesor Luis M. Macía. Madrid, Universidad Autónoma de Madrid, 2018. 
Religiones. (No) violencia y diálogo:

Contreras Mazarío, J. M. - Parejo Guzmán, M.J. (eds.): Religiones. (No) violencia y diálogo. Actas del XI Congreso de la Sociedad Española de Ciencias de las Religiones (Sevilla, 19 a 21 de mayo de 2016). Valencia, Tirant lo Blanch, 2018.

Studia Philologica et Diachronica in Honorem Joaquín Gorrochategui Indoeuropaea et Palaeohispanica:

Vallejo, J.M. - Igartúa, I. - García Castillero, C. (eds.) Studia Philologica et Diachronica in Honorem Joaquín Gorrochategui Indoeuropaea et Palaeohispanica, Anejos de Veleia, Series Minor 35. Vitoria, Universidad del País Vasco, 2018.

Visiones y aspectos puntuales de la épica grecorromana:

Estefanía, D. (ED.): Visiones y aspectos puntuales de la épica grecorromana. Manuales y Anejos de Emerita 53. Madrid, Consejo Superior de Investigaciones Científicas, 2018.

\section{AUTORES ANTIGUOS. EDICIONES, TRADUCCIONES Y ESTUDIOS}

\section{Acta Apostolorum Apocrypha}

Muñoz Gallarte, I.: "Aproximación a los Hechos Apócrifos de Tomás: La perla y la serpiente: un enfrentamiento en clave ética", Religiones. (No) violencia y diálogo 315-334.

Muñoz Gallarte, I.: "Fantasía y simbología en los Hechos Apócrifos de los Apóstoles: el relato del león bautizado en Acta Pauli", SPhV 20, 2018, 89-110.

Pomer Monferrer, J.J.: "Focs que no cremen en l'hagiografia tardoantiga i bizantina", PhV 20, 2018, 141-174.

PUig I TÀrRech, A.: Diez textos gnósticos. Traducción y comentarios. Estella, Verbo Divino, 2018.

\section{Aeschylus}

Bertolín Cebrián, R.: "De la superioridad intelectual a la moral en la Orestía de Esquilo", CFCG 28, 2018, 83-100.

BRUgnATELLI, P.: "Il matricidio come tabù: verosimiglianza dialògica ed eficacia dramatica della prima sticomitia delle Coefore", İtaca 34, 2018, 47-71.

Fernández Deagustini, M.P.: "Deber hacer, poder hacer: los dilemas de Pelasgo en Suplicantes de Esquilo, Habis 49, 2018, 25-42.

Lomiento, L.: "L'ingresso delle Erinni in Aesch. Eum. vv. 117-177: testo e metro, con alcune osservazioni dulla struttura formale dei vv. 117-139", İtaca 34, 2018, 31-46.

SÁNCHEZ i Bernet, A.: "Etèocles segons Èsquil: expressió lingüística dels conflictes d'un personatge", Tycho 6, 2018, 97-120. 


\section{Agathias}

Agatías: Historias. Guerras en Italia y Persia. Introducción, traducción y comentarios de R. García Ortega. Granada, Centro de Estudios Bizantinos, Neogriegos y Chipriotas, 2018.

\section{Alexander Aphrodisiensis}

GonZÁlez CAlderón, J.F.: "Formas de hacer filosofía en época imperial: Alejandro de Afrodisia y su

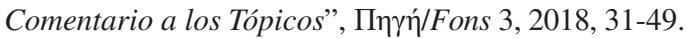

\section{Anonymus in Ptolemaei Tetrabiblon}

Caballero Sánchez, R.: "Sobre los signos que indican los deseos amorosos: problemas de autoría en torno a un texto astrológico transmitido en el Comentario Anónimo al Tetrabiblos de Tolomeo", Minerva 31, 2018, 133-158.

\section{Anthologia Graeca}

ERos gai (Antologia Palatina, llibre XII). Introducció de S. Grau. Traducció de J.J. Castelló. Martorell, Adeisara, 2018.

Gatsioufa, P.: "Aenigmata epigraphica: Ejercicios escolares y pasatiempos, entre tradición literaria y epigrafía", Nardus et myrto plexae coronae 133-144.

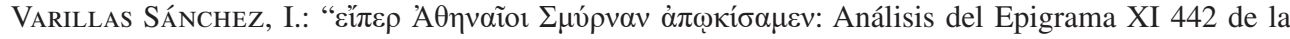
Antología Palatina", CFCG 28, 2018, 159-170.

\section{Antipater Sidonius}

Calderón, E.: "Estudio sobre el hexámetro de Antípatro de Sidón”, Phílos hetaîros 119-128.

\section{Aphthonius}

Arcos Pereira, T.: "Un nuevo ejemplar de los Aphthonii clarissimi rhetoris Progymnasmata, Ioanne Maria Catanaeo interprete, nunc denuo recognita iuxta ueritatem Graeci exemplaris \& scholijs illustrata per Ioannem Laurentium Palmyrenum Alcannizensem, FA 135.170 (1), en la Biblioteca Universitaria de la Universidad de Navarra", Myrtia 33, 2018, 419-42.

\section{Apocalypsis Enoch}

Flores Rivas, M.: "Unidos en la caída: Titanes y ángeles", Los orígenes del cristianismo en la literatura, el arte y la filosofía II, 41-60.

Sanz Extremeño, I.: "Quién es quién en el Apocalipsis de los animales de 1 Henoc II", Los orígenes del cristianismo en la literatura, el arte y la filosofía II, 61-78. 


\section{Apocalypses Iohannis Apocryphae}

Puig i TÀrrech, A.: Diez, textos gnósticos. Traducción y comentarios. Estella, Verbo Divino, 2018.

\section{Appianus}

Moralejo Álvarez, J.L.: "Las razones de la compasión: una nota sobre Liv. 25.24, Plb. 38.21-22, y App. 8 (Pun.) 132”, EClás.154, 2018, 41-50.

Rodríguez HorriLlo, M.Á.: "La voz autorial en la Historia romana de Apiano", CFCG 28, 2018, 207-224.

\section{Aratus}

Calderón Dorda, E.: "El programa poético de Arato", Visiones y aspectos puntuales de la épica grecorromana $57-78$.

\section{Aristophanes}

GonzÁlez VÁzquez, M.C.: "Lisístrata, la transgresión de la realidad y de la ficción”, Phílos hetaîros $55-64$

Navarro Martínez, V.L.: "El sociolecto femenino en la comedia griega: de Aristófanes a Menandro", Opera selecta 53-62.

Riu Camps, X.: "Espai i temps a la comèdia antiga. A propòsit de Acarnesos 237-240 i 440-444", AFAM 8, 2018, 792-796.

Santana Henríquez, G. - Espinosa Charri, I.-A-: "Aristófanes en Nicaragua: a propósito de la novela El país de las mujeres de Gioconda Belli”, Phílos hetaîros 293-303.

Vergara Recreo, S.: "El impacto social de la Guerra del Peloponeso a través de las comedias aristofánicas", Myrtia 33, 2018, 11-29.

\section{Aristoteles}

Aristóteles: Obra biológica. De partibus animalium. De motu animalium. De incessu animalium. Traducción del griego de R. Bartolomé. Introducción y notas de A. Marcos. Oviedo, KRK, 2018. Aristóteles: Reflexiones éticas. Edición de P. Ortiz, Barcelona, Ariel, 2018.

Arvelo, A.: Aristóteles o La precisión. Apuntes a la pasión del que nombra. Madrid, Solenodonte, 2018.

Bernabé, A.: "La Constitución de Atenas y el ideario político de Aristóteles", Phílos hetaîros 27 -36.

Bognolo, A.: "'Los libros de caballerías, de quien nunca se acordó Aristóteles': Cervantes, la Poética de Aristóteles y la crítica de la ficción", Ecos y resplandores helenos 427-448.

Escobar Chico, Á.: "Observaciones sobre la uetus translatio del De insomniis aristotélico y su reelaboración por Guillermo de Moerbeke", Emerita 86, 2018, 51-70.

Fialho, M.C.: "El potencial cognitivo de la mímesis en la Poética de Aristóteles", Nardus et myrto plexae coronae 105-116. 
Jiménez Torres, O.: Comentario a la Política de Aristóteles. Género-sujeto, principios y afecciones de la filosofía política. Pamplona, Eunsa, 2018.

Jiménez Torres, O.: Comentario a la Ethica Nicomachea de Aristóteles. Género-sujeto, principios y afecciones de la filosofía política. Pamplona, Eunsa, 2018.

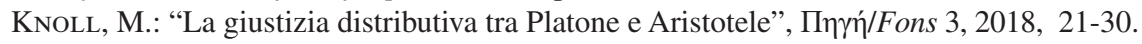

Minecan, A.M.C.: Fundamentos de física aristotélica. La estructura del cosmos y su ciencia. Madrid, Antígona, 2018.

Mora Alonso, C.A.: "La divisibilidad del alma en la psicología de Aristóteles. ¿Es posible conciliar el hilemorfismo y el ‘cardiocentrismo'?”, CFCG 28, 2018, 129-139.

Ortega Castro, M.: "Amistad y aristotelismo en la Francia del siglo XVI: las versiones latinas de la Política de Dionisio Lambino y Pierre de la Ramée", FI 29, 2018, 195-210.

RiAÑo, D.: "Hic non sunt dracones: el $\gamma \lambda$ óviৎ en Aristóteles y una crux desperationis en la Historia Animalium VII 602b20-28", Phílos hetaîros 147-156.

Torres Guerra, J.B.: "Reivindicando el Ciclo. La épica cíclica y el Margites en la Poética de Aristóteles", Phílos hetaîros 97-107.

Valenzuela Matus, C.: "Aristóteles en el Nuevo Mundo. La zona tórrida en las historias naturales jesuitas (siglos XVI-XVII)", 557-574.

ZoppI, F.: "Evolución del concepto aristotélico de ‘admiración' en los tratados poéticos de los siglos XVI y XVII", Ecos y resplandores helenos 535-556.

\section{Barnabae epistula}

Brotóns Merino, M.J.: "El diablo negro: el adjetivo $\mu \varepsilon ́ \lambda a \varsigma$ en la Septuaginta, Nuevo Testamento, Epístola de Bernabé y el Pastor de Hermas", CCO 15, 2018, 1-20.

PAdRes APOSTólicos: OBRAS ESCOGIDAS. Didaché. Cartas de Clemente. Cartas de Ignacio mártir. Carta y martirio de Policarpo. Carta de Bernabé. Carta a Diogneto. Fragmentos de Papías. Pastor de Hermas. Edición de A. Ropero Berzosa. Barcelona, Clíe, 2018.

\section{Basilius Caesariensis}

Gómez Cardó, P.: "Apuntes de un sofista cristiano en torno a la literatura griega: Ad adulescentes de Basilio el Grande", Emerita 86, 2018, 277-301.

\section{Biblia Graeca}

Aldave Medrano, M.E.: "La resurrección de Lázaro y la unción en Betania (Jn 11,1-12,11) a la luz del ritual de duelo de la antigüedad", $E B$ 76, 2018, 221-243.

Apocalipsis o LibRo de LA REVELACIÓN. Edición bilingüe de P. Lanceros. Madrid, Abada, 2018.

Armstrong, K.L.: "The end of Acts and the comparable age of its variants", FN 31, 2018, 87-110.

Barreto Betancort, J- Jorge Hernández, C.R. - García Díaz, M.M.: "Aproximación al estudio del campo semántico de los lexemas verbales de movimiento en el griego del Nuevo Testamento", FN 31, 2018, 17-31.

Bons, E. - Scialabba, D. - Cándido, D. - Passoni Dell'Acqua, A. - Bellantuono, A.: La Septuaginta. ¿Por qué resulta actual la Biblia griega? Estella, Verbo Divino, 2018.

Brotóns Merino, M.J.: "El diablo negro: el adjetivo $\mu \varepsilon ́ \lambda \alpha \varsigma$ en la Septuaginta, Nuevo Testamento, Epístola de Bernabé y el Pastor de Hermas", CCO 15, 2018, 1-20. 
Carbajosa Pérez, I.: Salmos I. Madrid, Biblioteca de Autores Cristianos, 2018.

Danove, P.: "A Method for Analyzing the Semantic and Narrative Rhetoric of Repetition and Their Contribution to Characterization", $E B$ 76, 2018, 55-84.

DANOve, P.: "Interpreting and translating $\gamma$ ívo $\mu \alpha$ as a verb of process in the New Testament", $F N 31$, 2018, 33-46.

Dodoson, N. - PAK, J.: "An examination of 2 Peter 1:19-21 and its Implications for understanding", $E B$ 76, 20I8, 385-410.

Durán MaÑas, M.: "Sor Juana Inés de la Cruz y su interpretación de 1Cor 14, $34-35$ en la respuesta a Sor Filotea de la Cruz", Los orígenes del cristianismo en la literatura, el arte y la filosofía II, 193-208.

Fernández Marcos, N.: "La Biblia griega de Alejandría y nuestra cultura occidental”, Los orígenes del cristianismo en la literatura, el arte y la filosofía II, 15-24.

Ferrández Zaragoza, N. - Polo Arrondo, J.: "Órdenes y prohibiciones de verbos sin control (( $\varphi$ -

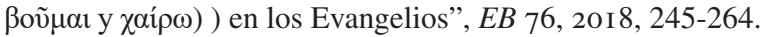

FilanNino, F.: "Riconoscere il tempo del regno: un'interpretazione "non-cristologica" di Mc 2, 18-20", $E B$ 76, 2018, 7-32.

Gómez Segura, E.: El cuerpo místico en San Pablo: un problema sintáctico. Tesis Doctoral. Universidad Complutense de Madrid, 2018.

GonzÁlez Alonso, P.: "El Hijo del Hombre de Jn 3,13 como revelador único frente a los visionarios apocalípticos", $E B$ 76, 20I8, 205-220.

LAfleur, D.: "Greek New Testament and purple Manuscrit: the case of Beratinus 1 ( $\otimes .043$ ) and Beratinus 2 (min. 1143)", FN 31, 2018, 47-86.

Mahfouz, H.: "Appearing to Them for Forty Days (Ac. 1,3)", EB 76, 20 I8, 361-384.

NiEto Alba, E.A.: "Pobres, marginados e indignados en el evangelio de Lucas", Los orígenes del cristianismo en la literatura, el arte y la filosofía II, 141-156.

Pérez Millós, S.: Comentario exegético al texto griego del Nuevo Testamento. Barcelona, Clíe, 2018.

PiÑero SÁenz, A.: "El Nuevo Testamento: la visión de un filólogo", $C F C G$ 28, 2018, 195-205.

PorTer, S.E.: "Revisiting the Greek verb: an extended critique", $F N$ 31, 2018, 3-16.

Rodgers, P.R.: "The question of 1 Peter 3:13", FN 31, 2018, 111-118.

SÁez Gutiérrez, A.: "Paternidad y filiación en la Carta a los Efesios", en Filiación VII. Cultura pagana, religión de Israel, orígenes del cristianismo. Edición de G. Cano Gómez, C. Sanvito, A. Sáez Gutiérrez. Madrid, Trotta, 2018, 45-82.

Rodríguez CARMona, A.: El cristianismo naciente. El cristianismo emergente a la luz de los Hechos de los Apóstoles. Madrid, Biblioteca de Autores Cristianos, 2018.

Steschke, C.: “ “... samt allen, die den Namen unseres Herrn Jesus Christus anrufen an jedem Ort, bei ihnen und bei uns' (1 Kor 1,2): übergemeindliche Verbindungen un ihre function im 1 Korintherbrief", $E B$ 76, 2018, 265-297.

Urbán, Á.: "Notas filológicas al texto griego y latino del Evangelio de Marcos en el Codex Bezae Cantabrigiensis (D 05 / d 5), Nardus et myrto plexae coronae 391-418.

Vegas Montaner, L.: "El judaísmo del Nuevo Testamento", Los orígenes del cristianismo en la literatura, el arte y la filosofía II, 25-40.

\section{Callimachus}

Calímaco: Himnos. Edición bilingüe de D.H. Errazúriz. Madrid, Cátedra, 2018.

Pérez Carrillo, C.: "La traducción de Poliziano del Himno al baño de Palas de Calímaco", Opera selecta $113-123$. 


\section{Charito}

Caritón de Afrodisias: Historia de Calírroe. Tradución do grego antigo de A.G. Rodríguez Alonso. Pontevedra, Rinoceronte, 2018.

\section{Christus patiens}

ACERBI, S.: "La transformación de los paradigmas clásicos en una controvertida tragedia cristiana", SPhV 20, 2018, 5-26.

\section{Chrysostomus, Iohannes}

JuAn Crisóstomo: Obras escogidas. La dignidad del ministerio. Sermón del monte. Salmos de David. Edición de A. Ropero Berzosa. Barcelona, Clíe, 2018.

\section{Clemens Alexandrinus}

Caballero Payá, D.: "La parresía en la obra de Clemente de Alejandría", Los orígenes del cristianismo en la literatura, el arte y la filosofía II, 225-240.

Gerónimo Llopis, Á.: Matrimonio y virginidad en Clemente de Alejandría desde una perspectiva antropológica-filosófica. Tesis doctoral, Universidad Católica de Valencia San Vicente Mártir, 2018.

Huerta Rodríguez, J.C.: Exégesis bíblica en Clemente de Alejandría. Uso e interpretación de las citas de los LXX (Pentateuco). Madrid, Consejo Superior de Investigaciones Científicas, 2018.

Ortiz García, P.: "Modelos morales mitológicos e históricos en Epicteto y en Clemente de Alejandría I: Pedagogo y Protréptico", Los orígenes del cristianismo en la literatura, el arte y la filosofía II, 311-328.

SÁnchez Madrid, N.: "Ascesis, enkráteia, gnôsis y agápe en los Stromateis de Clemente de Alejandría: la fabricación de la subjetividad cristiana", Los orígenes del cristianismo en la literatura, el arte y la filosofía II, 291-310.

\section{Clemens Romanus et Clementina}

Padres apostólicos: Obras escogidas. Didaché. Cartas de Clemente. Cartas de Ignacio mártir. Carta y martirio de Policarpo. Carta de Bernabé. Carta a Diogneto. Fragmentos de Papías. Pastor de Hermas. Edición de A. Ropero Berzosa. Barcelona, Clíe, 2018.

\section{Cleomedes}

Pediasimo, Juan: El comentario de Juan Pediasimo a los Cuerpos Celestes de Cleomedes. Edición crítica, traducción y estudio de la transmisión por P. Caballero Sánchez. Nueva Roma 48. Madrid, Consejo Superior de Investigaciones Científicas, 2018. 


\section{Cono}

IвÁÑEz Chacón, Á.: "Sobre Las cincuenta fábulas de Conón, traducidas por Cándido María Trigueros (1768)", EClás.154, 2018, 93-108.

\section{Corinna}

SÁNCHEZ i Bernet, A.: "Algunas particularidades de la flexión pronominal en Corina", Opera selecta $73-80$.

\section{Critias}

Soneira Martínez, R.: "Reflexiones de ateísmo e 'increencia' en torno al fragmento del Sísifo (DK 81, B25)”, 'Ilu 23, 2018, 279-304.

\section{Ctesias}

Ctesias de Cnido: Relaciones de la India. Edición bilingüe. Edición, traducción, notas y comentario de J. A. Álvarez-Pedrosa Núñez. Madrid, Dykinson, 2018.

\section{Didache siue Doctrina apostolorum}

Padres apostólicos: Obras escogidas. Didaché. Cartas de Clemente. Cartas de Ignacio mártir. Carta y martirio de Policarpo. Carta de Bernabé. Carta a Diogneto. Fragmentos de Papías. Pastor de Hermas. Edición de A. Ropero Berzosa. Barcelona, Clíe, 2018.

\section{Diogenes laertius}

Ruiz PéRez, P.: "Diógenes Laercio y las biografías literarias en la Edad Moderna", Ecos y resplandores helenos 605- 627.

\section{Empedocles}

KingSley, P.: Filosofía antigua, misterios y magia. Gerona, Atalanta, 2018.

\section{Ephorus}

Candau Morón, J.M.: "Estrabón, transmisor de Éforo", De nuevo sobre Estrabón 21-35. 


\section{Epictetus}

Ortiz García, P.: "Modelos morales mitológicos e históricos en Epicteto y en Clemente de Alejandría I: Pedagogo y Protréptico", Los orígenes del cristianismo en la literatura, el arte y la filosofía II, 311-328.

\section{Epicurus}

EPICuRo: Máximas del jardín. Edición de J.L. Gallero \& C.E. López. Madrid, Árdora, 2018.

MuÑoz Morcillo, J.: "El Kavóv de Epicuro en la Epístola a Heródoto", CFCG 28, 2018, 141-157.

\section{Epiphanius Constantiensis}

Puig I TÀrrech, A.: Diez textos gnósticos. Traducción y comentarios. Estella, Verbo Divino, 2018.

\section{Epistula ad Diognetum}

Padres Apostólicos: Obras escogidas. Didaché. Cartas de Clemente. Cartas de Ignacio mártir. Carta y martirio de Policarpo. Carta de Bernabé. Carta a Diogneto. Fragmentos de Papías. Pastor de Hermas. Edición de A. Ropero Berzosa. Barcelona, Clíe, 2018.

\section{Eroticorum Fragmenta Papyracea}

Artés Hernández, J.A.: "Novela de Nino: análisis de cláusulas métricas (Pab. "Berol”. 6926, PSI 1305)", Habis 49, 2018, 143-154.

\section{Euangelium Mariae}

Puig i TÀrrech, A.: Diez textos gnósticos. Traducción y comentarios. Estella, Verbo Divino, 2018.

\section{Euangelium Philippi}

PUig i TÀrrech, A.: Diez textos gnósticos. Traducción y comentarios. Estella, Verbo Divino, 2018.

\section{Euangelium Thomae}

Puig i TÀrrech, A.: Diez textos gnósticos. Traducción y comentarios. Estella, Verbo Divino, 2018.

\section{Euclides}

Pastor Botella, L.: "Euclides en España (siglos XV y XVI)”, Tempus 43, 2018, 7-12. 
Pla i Carrera, J.: Història de la Matemàtica. Grècia IIa (Els Elements d'Euclides, Llibres I, II, III, IV, V $i$ VI). Resultats, textos i contextos. Barcelona, Institut d'Estudis Catalans, 2018.

\section{Euripides}

Calero Secall, I.: "La figura del padre y las relaciones paterno-filiales dentro del oĩ̄o en las obras de Eurípides", EClás.154, 2018, 19-40.

Camino, M.E. - Moulins, A.: "Medea en la pampa argentina", Thamyris 9, 2018, 257-274.

Carvallo Carvallo, B.: Lecturas del mito de Electra. Una lectura com parada entre las versiones del mito en Eurípides y en Jean Paul Sartre. Madrid, Académica Española, 2018.

EuRíPIDES: TRAGEDIAS VIII. Troyanas. Ion. Introducción, texto revisado y traducción de A. Guzmán Guerra. Colección Alma Mater. Madrid, Consejo Superior de Investigaciones Científicas, 2018.

PerczyK, C.: La locura en Heracles y Bacantes de Eurípides. Una lectura en el cruce entre la filología clásica y el psicoanálisis. Madrid, Miño y Dávila, 2018.

Pérez Gómez, L.: "Del mito de Medea al `Síndrome de Medea'”, FI 29, 2018, 211-238

SÁNCHEZ MADRID, N.: El silencio y la furia. Religión y política en Eurípides. Tesis doctoral. Madrid, Universidad Complutense de Madrid, 2018.

Solís de ovando Donoso, M.L.: La esencia trágica de Ión, Ifigenia entre los Tauros, Helena, Orestes y Andrómeda, de Eurípides: una nueva interpretación. Tesis doctoral. Madrid, Universidad Autónoma de Madrid, 2018.

\section{Eusebius Caesariensis}

PAJón Leyra, I.: "La recepción del helenismo en Eusebio de Cesarea: polémica y asimilación", Los orígenes del cristianismo en la literatura, el arte y la filosofía II, 351-370.

\section{Eustathius Thessalonicensis}

Kolovou, G.E.: "Homère chez Eustathe de Thessalonique: la traduction des Proèmes sur l'Iliade et l'Odyssée", CCO 15, 2018, 71-118.

\section{Galenus}

FISCHER, K.-D.: "Drugs to declare. Two pharmaceutical works attibutes to Galen", $C F C G$ 28, 2018, 225-241.

Cerezo Magán, M.: Galeno, pionero del nutricionismo. Lérida, Universidad, 2018.

LÓPEZ FÉREZ, J.A. (ED.): Galeno, preparación y constitución de textos críticos, entrega y publicación de obras propias o ajenas. Madrid, Ediciones Clásicas, 2018

Pino Campos, L.M.: "Doctrina de Galeno sobre las causas en los pulsos. III: casos y comentarios", Phílos hetaîros 87-96. 


\section{Gorgias}

Chialva, I.S.: "Hacia una poética aporética: de la interpretación a la traducción en cuatro pasajes de En Defensa de Palamedes de Gorgias", Minerva 31, 2018, 61-80.

\section{Heraclitus}

Capizzi, A.: Heráclito y su leyenda. Propuesta de una lectura diferente de los fragmentos. Zaragoza, Universidad, 2018.

\section{Hermas}

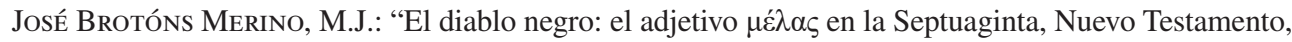
Epístola de Bernabé y el Pastor de Hermas", CCO 15, 2018, 1-20.

Padres apostólicos: ObRAS escogidas. Didaché. Cartas de Clemente. Cartas de Ignacio mártir. Carta y martirio de Policarpo. Carta de Bernabé. Carta a Diogneto. Fragmentos de Papías. Pastor de Hermas. Edición de A. Ropero Berzosa. Barcelona, Clíe, 2018.

\section{Herodotus}

Camps Vives, E.: "Destino y costumbre en Heródoto: la desgracia de Candaules", Habis 49, 2018, 7-23. Heródoto: La Batalla de las Termópilas. Traducción de A. Echevarren. Barcelona, Edhasa, 2018.

SÁnChez MaÑAs, C.: "Retórica del parentesco en la biografía temprana de Ciro (Hdt. 1.107-130)", Talia dixit 13, 2018, 1-25.

\section{Hesiodus}

Konrádová, V.: "God and Justice in Hesiod and Plato: Interpreting the Myth of Protagoras (Prot.

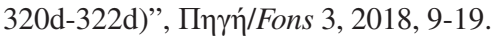

López SACO, J.: "La configuración del héroe épico griego arcaico a través de Homero y Hesíodo", en El Futuro del Pasado 9, 2018, 157-176 (www.elfuturodelpasado.com/ojs/index.php/FdP/article/ view/310)

\section{Hierocles facetiarum scriptor}

Camps i Gaset, M.: "Acudits grecs sobre universitaris. El Philogelos i els problemes del terme

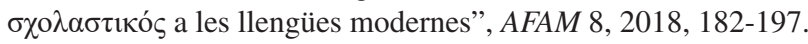

\section{Hippocrates et Corpus Hippocraticum}

ÁNGEL EsPINós, J.: "Sobre una fórmula común en los tratados hipocráticos Enfermedades II y Afecciones Internas", Myrtia 33, 2018, 31-55. 


\section{Homerus}

Abritta, A.: "Sobre las violaciones de la ley de Hermann en Homero", EClás.153, 2018, 49-70.

BASILE, G.J.: "The Homeric ǐ $\sigma \omega \rho$ and oath-taking", $C F C G$ 28, 2018, 17-39.

Bernabé Pajares, A.: "Hombres y dioses en la Ilíada", Visiones y aspectos puntuales de la épica grecorromana 33-56.

BertocCI, D.: "Considerazioni sintattiche sulla tmesi in Omero", Classical languages and linguistics 87-IO2.

Blanco, S.: "La tradición indirecta en el canto XXII de la Ilíada", Phílos hetaîros 109-118.

Calvo Martínez, J.L.: "La búsqueda del Más Allá como estructura profunda de las aventuras de la Odisea", Nardus et myrto plexae coronae 35-44.

Crespo, E.: "Los enunciados parentéticos en la Ilíada", Phílos hetaîros 219-228.

DE LA Villa, J.: "Variantes textuales de naturaleza aspectual en la Iliada", Phílos hetaîros 175-187.

Galindo Esparza, A.: "Traducciones femeninas de Homero: un microrrelato y sus antecedentes clásicos”, EClás.153, 2018, 105-124.

GonZÁlez Vaquerizo, H.: "Libertad o muerte. Una Ilíada cretense (y modernista)", Phílos hetaîros 265-272,

Homero: ODISEA. Adaptación, notas y glosario onomástico de A. Garcia Llorca. Valencia, Teide, 2018.

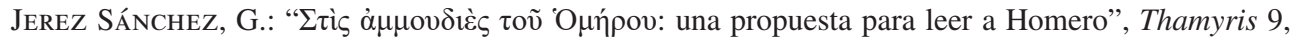
2018, 213-228.

Kolovou, G.E.: "Homère chez Eustathe de Thessalonique: la traduction des Proèmes sur l'Iliade et l'Odyssée", CCO 15, 2018, 71-118.

López SACO, J.: "La configuración del héroe épico griego arcaico a través de Homero y Hesíodo", en El Futuro del Pasado 9, 2018, 157-176 (https://www.elfuturodelpasado.com/ojs/index.php/FdP/ article/view/310)

Martos Fornieles, M.: “Alloglossia: diversidad de lenguas en la épica griega arcaica”, FI 29, 2018, 111-149.

MedDA, E.: "Odisseo a Itaca: il monologo di Od. XIII 187-221 fra critica analitica e poetica dell'ironia (con una nota su Il Ritorno di Giovanni Pascoli)", İtaca 34, 2018, 7-29.

Míguez Barciela, A.: "Krísis como proceso cognoscitivo en la Odisea", Convergencias y divergencias $137-154$.

Moya DEL BAÑo, F.: "Homero en Quevedo. Notas de lectura", Ecos y resplandores helenos 161-186.

MuÑoz González, D.: "Masculinidad hegemónica y alteridad: los "viejos" en la Ilíada", Las edades vulnerables 231-245.

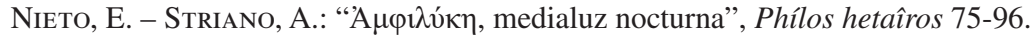

Polo, J.: "Digresiones en Ilíada, una propuesta pragmática", Phílos hetaîros 229-242.

Rodríguez Blanco, M.E.: "Penélope vuelve a tejer", Phílos hetaîros 281 -292.

STRIPEIKIS, C.: "El sueño de los gansos y las puertas de cuerno y marfil como recursos para mantener la tensión narrativa en el reencuentro de Odiseo y Penélope (“Od.” 19.535-583)”, EClás.153, 2018, $33-48$.

Valverde, M.: "El Codex Matritensis Gr. B.N. 4565 de la Odisea y la edición Allen: necesidad de una revisión", Phílos hetaîros 163-174.

\section{Iamblichus scriptor eroticus}

Librán Moreno, M.: “Dioses y animales en Babiloníacas de Jámblico”, Myrtia 33, 2018, 155-174. 


\section{Ignatius Antiochenus}

Padres apostólicos: ObRas escogidas. Didaché. Cartas de Clemente. Cartas de Ignacio mártir. Carta y martirio de Policarpo. Carta de Bernabé. Carta a Diogneto. Fragmentos de Papías. Pastor de Hermas. Edición de A. Ropero Berzosa. Barcelona, Clíe, 2018.

\section{Iulianus imperator}

Redondo Moyano, E.: "La construcción de una identidad política: La carta de Juliano el Apóstata Al Senado y al pueblo de Atenas", İtaca 34, 2018, 147-171.

\section{Iustinus Martyr philosophus et Pseudo Iustinus}

Rivas Rebaque, F.: "El cristianismo como mestizaje cultural. Apropiación de la Escritura judía por parte cristiana en Justino Mártir", EB 76, 2018, 115-144.

Torrijos Castrillejo, D.: "La noción de providencia según San Justino", Los orígenes del cristianismo en la literatura, el arte y la filosofía II, 271-290.

\section{Longus}

Longo: DAFNIS Y CLOE. Traducción de P. Olalla, Madrid, De Conatus, 2018.

\section{Lucianus}

Gassino, I.: "Les Dialogues des Courtisanes: des dialogues lucianesques?", İtaca 34, 2018, 117-146.

Luciano de Samósata: El Sueño o La VIDa de LuCiano. Lucio o El asno. El sueño o El gallo. Lexiufano. Edición de A. Rodríguez López-Vázquez, Madrid, Cátedra, 2018.

Mestre, F. - Gómez i Cardó, P.: "Llucià i el culte imperial”, AFAM 8, 2018, 560-574.

Redondo Pérez, G.: "Calumnia y Vitarum auctio: dos obras de Luciano traducidas por Sancho Bravo de Lagunas", Ecos y resplandores helenos 409-426.

Rodríguez Alfageme, I.: "Fuentes para una traducción: Laguna, Tragopodagra", Cal.Ren.18, 2017, 245-268.

\section{Magica}

Albrile, E.: "Costruire il Caos. Alle origine della magia salomonica", MHNH 17, 2017, 5-40.

Casella, V.: "Ecate in Dacia tra lattanza e assimilazione", $M H N H$ 17, 2017, 41-64.

Gordon, R.: "Desire, Gossip, Uncertainty and Magic in Graeco-Roman Antiquity", $M H N H$ 17, 2017, 65-102.

Heilen, S. - Mastrocinque, A.: "A Third Horoscope-Gem, Twin of the Parisian 'Seyrig Gem”, MHNH 17, 2017, 103-168.

López-CARrasco, N.: "La Osa y Hécate en la Invocación de PGM VII 686-702", $M H N H$ 17, 2017, 139-166. 
Martín Hernández, R.: "El poder de las imágenes en la magia a partir del s. IV d.C. Las representaciones de Jesús", Los orígenes del cristianismo en la literatura, el arte y la filosofía II, 255-268.

\section{Margites}

Torres Guerra, J.B.: "Reivindicando el Ciclo. La épica cíclica y el Margites en la Poética de Aristóteles", Phílos hetaîros 97-107.

\section{Martyrium Perpetuae et Felicitatis}

Sardella, T.: "Dai miti classici ai miti cristiani. Tempo e mirabilia nelle passiones storiche e nell'agiografia siciliana", SPhV 20, 2018, 175-194.

\section{Martyrium Polycarpi}

Padres apostólicos: ObRAS ESCOGIDAS. Didaché. Cartas de Clemente. Cartas de Ignacio mártir. Carta y martirio de Policarpo. Carta de Bernabé. Carta a Diogneto. Fragmentos de Papías. Pastor de Hermas. Edición de A. Ropero Berzosa. Barcelona, Clíe, 2018.

\section{Menander}

Curnis, M.: "Demetrio Ducas y la edición de los Erotemata Chrysolorae (1514), entre Venecia y Alcalá

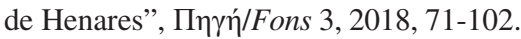

Navarro Martínez, V.L.: "El sociolecto femenino en la comedia griega: de Aristófanes a Menandro", Opera selecta 53-62.

\section{Monumentum Ancyranum Graecum}

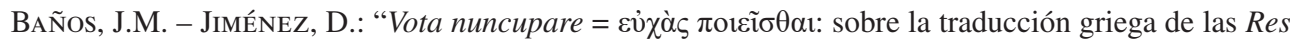
Gestae de Augusto", Phílos hetaîros 189-208.

\section{Nicander}

Esteve, P.J.: Nicandri Theriaca. Traducción latina en verso (1552). Introducción, edición crítica, traducción y notas de M.T. Santamaría Hernández. Cuenca, Universidad de Castilla-La Mancha, 2018.

\section{Oppianus Anazarbensis}

Martínez, M.: "Erotica animalia II: Aspectos eróticos y amorosos en Opiano”, Phílos hetaîros 65 -74. 


\section{Oppianus Apamensis}

Martínez, M.: “Erotica animalia II: Aspectos eróticos y amorosos en Opiano”, Phílos hetaîros 65 -74.

\section{Origenes}

López Martín, I.: "Orígenes y Celso: dos visiones de la divinidad", Los orígenes del cristianismo en la literatura, el arte y la filosofía II, 329-348.

\section{Orphica}

Bernabé Pajares, A.: "La cosmogonía de las Metamorfosis de Ovidio y las Rapsodias órficas", Emerita $86,2018,207-232$.

\section{Papias Hieropolitanus}

Padres apostólicos: OBRAS escogidas. Didaché. Cartas de Clemente. Cartas de Ignacio mártir. Carta y martirio de Policarpo. Carta de Bernabé. Carta a Diogneto. Fragmentos de Papías. Pastor de Hermas. Edición de A. Ropero Berzosa. Barcelona, Clíe, 2018.

\section{Parmenides}

Marieta, I.: "Parménides y la globalización: la política sin poetas", Convergencias y divergencias 181-200.

PARMÉNIDES. Edición crítica, versión rítmica y paráfrasis de los fragmentos del poema por A. García Calvo, editadas con prolegómenos, comentario y texto de las fuentes y los testimonios indirectos por L.A. Bredlow. Madrid, Lucina, 2018.

\section{Pausanias}

López Calahorro, I.: "La recepción del legado de Pausanias en el paisaje argelino de Albert Camus: de Chateaubriand a James G. Frazer", Myrtia 33, 2018, 321-341.

\section{Philo Iudaeus}

Rodríguez Hevia, T.: Filón de Alejandría. De ebrietate. Uso de los tópicos filosóficos griegos. Madrid, Ediciones Universidad San Dámaso, 2018.

\section{Plato}

CAmpbell, Y.: "Presencia platónica en Examen de maridos de Juan Ruiz de Alarcón", Ecos y resplandores helenos 291-308. 
Cantarero de Salazar, A.: "Sobre el filósofo hispalense Sebastián Fox Morcillo: de comentarista (Timeo, Fedón y República) a imitador de Platón”, Ecos y resplandores helenos 575-604.

Kebadze, N.: "El acervo platónico en Memorias de Leticia Valle (1945) de Rosa

CHACEL", ECOS Y RESPLANDORES HELENOS 383-392.

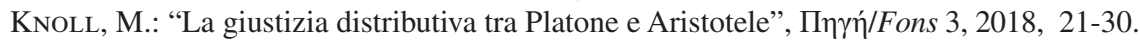

Konrádová, V.: "God and Justice in Hesiod and Plato: Interpreting the Myth of Protagoras (Prot.

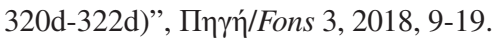

Lisi Bereterbide, F.L.: "República VII 517a8-521c1”, Emerita 86, 2018, 233-252.

Macua Martínez, E.: "La domesticación de éros y poesía en las Leyes: la síntesis platónica de vida y poesía", CFCG 28, 2018, 115-128.

Mavrelos, N.: "El Criticón como reflejo del mito platónico de la caverna en el mundo cristiano de la modernidad temprana: intertextualidad e ideología”, Ecos y resplandores helenos 393-408.

Méndez Aguirre, V.H.: "El mito de la autoctonía en la Atenas de Platón: entre religión, magia y política", Convergencias y divergencias 17-40.

Obarrio Moreno, J.A.: Un estudio sobre la antigüedad. La Apología de Sócrates. Madrid, Dykinson, 2018.

Platón: EL BANQUETE. Traducción de Ángel Narro. Tarragona, Rhemata, 2018.

Sierra González, Á.: "Platón y el derecho del más fuerte", Convergencias y divergencias 155-180.

Vallejo Campos, A.: Adonde nos lleve el logos. Para leer la República de Platón. Madrid, Trotta, 2018.

\section{Plotinus}

FERnÁNDez, A.: "Plotino en San Agustín: interioridad y Neoplatonismo", Los orígenes del cristianismo en la literatura, el arte y la filosofía II, 371-384.

\section{Plutarchus}

Lesage GÁrRiga, L.: "Aldinas anotadas: una puesta al día de la contribución de los humanistas a través del estudio de De facie", CFCG 28, 2018, 243-265.

MÉndez Santiago, B.: "Vulnerabilidad infantil en las Vidas paralelas de Plutarco", Las edades vulnerables $87-110$.

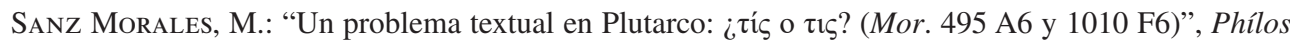
hetaîros 157-162.

SAPERE, A.V.: "Ficción y verdad en las Vidas paralelas de Plutarco", Emerita 86, 2018, 27-50.

\section{Polybius}

Moralejo Álvarez, J.L.: "Las razones de la compasión: una nota sobre Liv. 25.24, Plb. 38.21-22, y App. 8 (Pun.) 132”, EClás.154, 2018, 41-50.

\section{Porphyrius Tyrius}

SÁnchez de Mayo, P.: "La crítica a la violencia religiosa contra los animales en la obra De abstinentia de Porfirio de Tiro: el caso de los sacrificios cruentos", Religiones. (No) violencia y diálogo 99-114. 


\section{Protagoras}

Schiappa, E.: Protágoras y el logos. Un estudio sobre filosofía y retórica. Madrid, Avarigani, 2018.

\section{Proteuangelium Iacobi}

Barcellona, R.: "Echi dal mondo antico nel racconto della natività: il Protoevangelium Jacobi e il Liber de nativitate Salvatoris", SPhV 20, 2018, 27-46.

\section{Rhintho}

Querol Donat, J.: "Breves notas sobre la lengua de Rintón y el antiguo dialecto griego de Tarento", CFCG 28, 2018, 9-16.

\section{Sophocles}

Adams, S.: Antígona. El derecho frente a la conciencia. Tesis doctoral. Valencia, Universidad Católica de Valencia San Vicente Mártir, 2018.

Pérez Lambás, F.: “Técnica teatral y paradojas en los prólogos de Sófocles”, Minerva 31, 2018, 35-60.

\section{Strabo}

Candau Morón, J.M.: "Estrabón, transmisor de Éforo", De nuevo sobre Estrabón 21-35.

Castro-Paez, E. - Moret, P.: "Iberia y Galia en Estrabón. Elaboración cartográfica y aspectos histórico-culturales", De nuevo sobre Estrabón 73-107.

Cohen-Skalli, A. - Marcotte, D.: "Guarino Veronese, annotateur de Strabon. Observations sur le Bodleianus Canonici Class. Lat. 301", De nuevo sobre Estrabón 137-159.

Dueck, D.: "Traditions, trends and topics in Strabonian studies", De nuevo sobre Estrabón 3-18.

Gómez Espelosín, F.J.: "De Estrabón a Alejandro", De nuevo sobre Estrabón 37-56.

Pérez Martín, I.: "Miguel Pselo, Sobre el mapa: un Estrabón oculto", De nuevo sobre Estrabón 111135.

Prontera, F.: “Strabone e la cartografia ellenistica”, De nuevo sobre Estrabón 59-71.

\section{Themistius}

Torre Beivide, A.: "Sobre la identidad de Polidamante y Glauco en Temistio Or. 1,7b", Minerva 31, 2018, 81-91.

\section{Theocritus}

Abritta, A.: "Preliminares para un análisis métrico-acentual de la poesía de Teócrito", Emerita 86, 2018, 1-25. 


\section{Thucydides}

Guantes García, J.: "La otra cara del sufrimiento: la presencia de los niños en la guerra del Peloponeso", Las edades vulnerables 61-86.

Silva, M.F.: "Da criação de uma cidade até à cidade perfeita: Tucídides e o passado da Grécia “, Nardus et myrto plexae coronae 377-390.

\section{Xenopho}

Batezzato, L.: "Una congettura a Pseudo-Senofonte, Costituzione degli Ateniesi 2, 19", İtaca 34, 2018, 73-79.

Carbonell Martínez, S. - Garrido Castelló, M.: "Las Helénicas de Jenofonte: una selectividad diferente es posible", Thamyris 9, 2018, 155-172.

JENOFONTE: ANÁBASIS. Arganda del rey, Verbum, 2018.

Jenofonte: LA MARCHA DE LOS DIEZ MIL. Traducción de A. Echavarren. Barcelona, Edhasa, 2018.

\section{HISTORIA DE LA LITERATURA}

BAPTISTA SÁnchez, A.I.: "Aproximación a la poesía didáctica griega fragmentaria de época helenística", Opera selecta 23-34.

BellucCI, N.: "Brevi note su alcuni autori e testi di gastronomia del periodo greco-romano", Helmantica 69(201-202), 2018, 37-66.

Bermejo Rubio, F.: "El concepto de muerte vicaria en el mondo grecorromano y su influencia en la primera reflexión cristiana sobre la muerte de Jesús de Nazaret”, SPhV 20, 2018, 47-71.

Blanco Cesteros, M.: "El complejo mundo de la retórica mágica: una mirada más allá de la coacción", 171-193.

Blanco LóPez, R.: La historia del pueblo peonio. Recogida y análisis crítico de las fuentes literarias griegas y romanas. Tesis Doctoral. Tarragona, Universidad Rovira i Virgili, 2018.

Calero, L.: "El coro dramático y la falange de los hoplitas", Phílos hetaîros 37-44.

Carbonell, A. - Miró Vinaixa, M.: La musa dels nois. Poesía homoeròtica grega antiga. Gerona, L'Art de la Memòria, 2018.

Cavallero, P.: La tragedia después de la tragedia. La evolución del género dramático desde el siglo IV a.C. Granada, Centro de Estudios Bizantinos, Neogriegos y Chipriotas, 2018.

Colangelo, E.: "La mer, l'euploia gravée et les épigrammes thalassiques à forme hymnique: le `paysage énonciatif maritime' en question", Antesteria 7, 2018, 135-151.

Criado Boado, C.: "Seges Horruit hastis (Virg., G. II 140-143). Mieses enhiestas y labranzas funestas en la épica grecorromana", Visiones y aspectos puntuales de la épica grecorromana 79-102.

EnCinAs Reguero, M.C.: "El viaje en la tragedia griega", $C F C G$ 28, 2018, 101-113.

Fernandez Delgado, J.A. - PoRdomingo, F.: La retorica escolar griega y su influencia literaria. Edicion a cargo de J. Ureña y L. Miguélez-Cavero. Salamanca, Universidad, 2018.

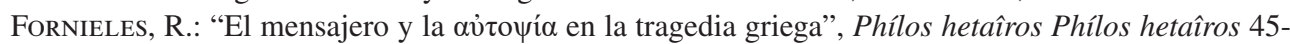
54.

García Trabazo, J.V.: "Reflejos de la tradición indoeuropea en la épica griega", Visiones y aspectos puntuales de la épica grecorromana 13-32.

Gómez Luque, J.A.: El tópico literario de la travesía del amor: de la literatura clásica a la poesía española de los Siglos de Oro. Córdoba, Universidad, 2018. 
Hualde Pascual, P.: "Metáforas del amor en la poesía de la Grecia antigua (II): De la tragedia ática a la poesía helenística", $C F C G$ 28, 2018, 41-81.

MuÑoz Martínez, S.: "Experiencia de la mors immatura según la epigrafía y la tragedia griegas", Tycho 6, 2018, 75-96.

Rodríguez Alonso, M.: La teoría de la literatura y literatura comparada desde el mundo clásico. Murcia, Universidad de Murcia, 2018.

SANZ, D.F.: "El fenómeno del canibalismo en las fuentes literarias grecorromanas: su mención en la historiografía", Myrtia 33, 2018, 199-234.

Torres Prieto, J.M.: "Las disputas contra paganos en la Antigüedad tardía: entre el diálogos y la disputatio", SPhV 20, 2018, 217-242.

Vidal Vega, J.: Speculum Historiae. Antecedentes histórico-literarios de la crónica en el mundo antiguo. Sevilla, Alfar, 2018.

\section{LINGÜÍSTICA GRIEGA. MÉTRICA}

Abritta, A.: "Sobre las violaciones de la ley de Hermann en Homero", EClás.153, 2018, 49-70.

Aquilué, X. - Ayensa, E.: "Rode/Rhode. Proposta de transcripció del topònim de la colònia grega de

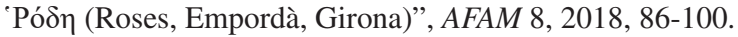

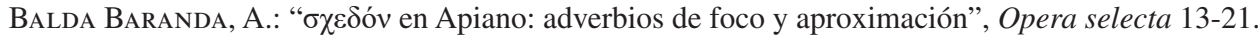

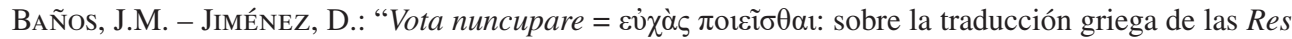
Gestae de Augusto", Phílos hetaîros 189-208.

Barreto Betancort, J- Jorge Hernández, C.R. - García Díaz, M.M.: "Aproximación al estudio del campo semántico de los lexemas verbales de movimiento en el griego del Nuevo Testamento", FN 31, 2018, 17-31.

Brotóns Merino, M.J.: "El diablo negro: el adjetivo $\mu \varepsilon ́ \lambda \alpha \varsigma$ en la Septuaginta, Nuevo Testamento, Epístola de Bernabé y el Pastor de Hermas", CCO 15, 2018, 1-20.

Bertocci, D.: "Considerazioni sintattiche sulla tmesi in Omero", Classical languages and linguistics 87-I02.

Calderón, E.: "Estudio sobre el hexámetro de Antípatro de Sidón", Phílos hetaîros 119-128.

CAssio, A.C.: "Escritura y poder en la Grecia arcaica: el caso de Creta y Chipre", EClás.153, 2018, 13-30.

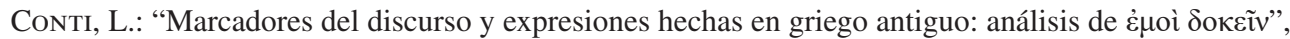
Phílos hetaîros 209-218.

Crespo, E.: "Los enunciados parentéticos en la Ilíada", Phílos hetaîros 219-228.

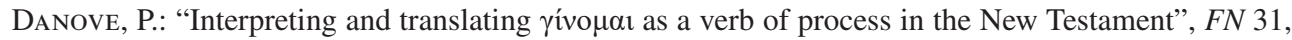
2018, 33-46.

DARDANO, P.: "Nominalizzazioni e struttura argomentale: su alcuni nomi deverbali del greco antico", Classical languages and linguistics I27-I42.

Elvira Astoreca, N.: "Escritura e identidad: el caso de Pafos", Opera selecta 35-43.

García Toral, A.: "Usos modales en los dialectos griegos: valores epistémicos", Opera selecta 45-52.

García Trabazo, J.V.: "Sobre gr. $\tau \dot{c} \rho \alpha \varsigma$ ‘signo (divino), prodigio' y sánscr. ava-tārá- 'descenso (desde el cielo), encarnación'”, Studia Philologica et Diachronica in Honorem Joaquín Gorrochategui Indoeuropaea et Palaeohispanica 171-180.

Hernández, F.: "Egometría en el verso griego: trímetro yámbico y hexámetro dactílico (con algunas consideraciones sobre el latino)", Phílos hetaîros 129-146.

MARTínez, R.: "The theory of discourse markers and conjunctive adverbs in ancient Greek. The role of informative structure in defining the conjunctive function", Classical languages and linguistics I59-I72. 
Martos Montiel, J.F.: "Una propuesta de estudio del léxico sexual griego: los textos astrológicos", EC 22, 2018, 65-90.

Méndez Dosuna, J.: "El origen de la preposición à `a casa de"”, Studia Philologica et Diachronica in Honorem Joaquín Gorrochategui Indoeuropaea et Palaeohispanica 313-330.

Moncó Taracena, B: “'Bad GreeK' in the documentary Papyri”, Classical languages and linguisTICS 43-56.

Navarro Martínez, V.L.: "El sociolecto femenino en la comedia griega: de Aristófanes a Menandro", Opera selecta 53-62.

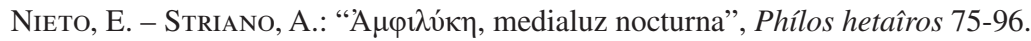

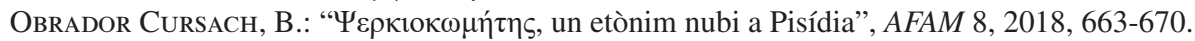

Pompeo, F. - Álvarez Pedrosa, J.A. - Benvenuto, M.C.: Del Indo al Egeo. Relaciones culturales y lingüísticas en el interior del Imperio aqueménida. Madrid, Escolar y Mayo, 2018.

PorTer, S.E.: "Revisiting the Greek verb: an extended critique", FN 31, 2018, 3-16.

Querol Donat, J.: "Breves notas sobre la lengua de Rintón y el antiguo dialecto griego de Tarento", CFCG 28, 2018, 9-16.

Redondo Moyano, E.: "El adverbio conjuntivo ö $\mu \omega \varsigma$ combinado con otros conectores: el caso de ö $\mu \omega \varsigma "$, Classical languages and linguistics I73-184.

Redondo Moyano, E.: "Multifuncionalidad y polisemia: descripción sintáctica, semántica y pragmática del griego oủoé", Emerita 86, 2018, 303-326.

Ruiz Yamuza, E.: "La periferia derecha y los tipos de texto en griego antiguo", Minerva 31, 2918, 13-34.

SÁNCHEZ i Bernet, A.: "Algunas particularidades de la flexión pronominal en Corina”, Opera selecta 73-80.

TroncI, L.: "Sulla flessione verbale in greco antico", Classical languages and linguistics 75-86.

\section{MICENOLOGÍA}

PiQuero Rodríguez, J.: “Los vidrieros del “centro de culto” de Micenas”, Opera selecta 63-72.

\section{EPIGRAFÍA. PAPIROLOGÍA. NUMISMÁTICA}

DE Tord Basterra, G.: Maldiciones y dedicatorias en el Occidente mediterráneo: epigrafía local sobre láminas metálicas", Antesteria 7, 2018, 185-206.

Gatsioufa, P.: "Aenigmata epigraphica: Ejercicios escolares y pasatiempos, entre tradición literaria y epigrafía", Nardus et myrto plexae coronae 133-144.

Martín Abad, J.: Cum figuris. Texto e imagen en los incunables españoles. Madrid, Arco, 2018.

Muñoz Martínez, S.: "Experiencia de la mors immatura según la epigrafía y la tragedia griegas", Tycho 6, 2018, 75-96.

\section{HISTORIA DE LOS TEXTOS}

Blanco, S.: "La tradición indirecta en el canto XXII de la Ilíada", Phílos hetaîros 109-118.

Curnis, M.: "Demetrio Ducas y la edición de los Erotemata Chrysolorae (1514), entre Venecia y Alcalá

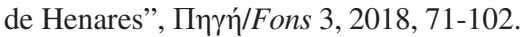

DE LA Villa, J.: "Variantes textuales de naturaleza aspectual en la Iliada", Phílos hetaîros 175-187. 


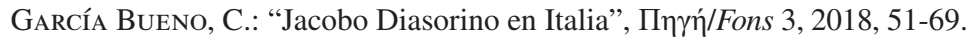

LAfleur, D.: "Greek New Testament and purple Manuscrit: the case of Beratinus 1 (Ф. 043) and Beratinus 2 (min. 1143)", FN 31, 2018, 47-86.

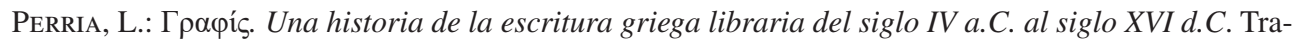
ducción de L. Benassi e I. Pérez Martín. Madrid, Universidad San Dámaso, 2018.

VAlverde, M.: "El Codex Matritensis Gr. B.N. 4565 de la Odisea y la edición Allen: necesidad de una revisión", Phílos hetaîros 163-174.

\section{HISTORIA. CULTURA. SOCIEDAD}

AA.VV.: Deporte, espectáculo y religión en el mundo antiguo. Volumen monográfico de Arys = Arys 15, 2017.

AA.VV.: Deis gratias. Diversidad religiosa y política imperial en el s. II d.C. Volumen monográfico de Arys $=$ Arys 16, 2018.

AA.VV.: Músicas en la Antigüedad. Madrid, Ediciones Invisibles, 2018.

Agudo Villanueva, M.: Atenas: el lejano eco de las piedras. Prólogo de C. García Gual. Almería, Confluencias, 2018.

Antela Bernárdez, B.: Hellenismus. Ensayos de historiografía. Zaragoza, Pórtico, 2018.

Chaniotis, A.: La era de las conquistas. El mundo griego de Alejandro a Adriano (336 a.C.-138 d. C.) Traducción de D. León Gómez. Barcelona, Pasado \& Presente, 2018.

Barceló, P. - Hernández de la Fuente, D.: Breve historia política de la Grecia Clásica: de Clístenes a Pericles. Salamanca, Escolar y Mayo, 2018.

Delgado Escolar, F.L. (COORD.) ET Alit: Vino, cultura y mundo clásico. Logroño, Instituto de Educación Secundaria Hermanos D’Elhuyar, 2018.

Díaz Sánchez, C.: Breve historia de las batallas de la Antigüedad. Egipto, Grecia, Roma. Madrid, Nowtilus, 2018.

Duplá Ansuategui, A. - Dell'Elicine, E. - Pérez Mostazo, J. (eds.): Antigüedad clásica y naciones modernas en el Viejo y el Nuevo Mundo. Madrid, Polifemo, 2018.

Ferrer Albelda, E. - Pereira Delgado, A. (eds.): Los negocios de Plutón. La economía de los santuarios y templos en la Antigüedad. Sevilla, Universidad, 2018.

Gallego, J.: La anarquía de la democracia. Asamblea ateniense y subjetivación del pueblo. Madrid, Miño y Dávila, 20 I 8.

García Barrios, A. - Ozcáriz Gil, P. - Rodríguez Cerezo, T.M.: Viajes y viajeros en el mundo antiguo y medieval. Madrid, Dykinson, 2018.

García Mora, F.: Atlas de Historia Antigua. Volumen III: La Antigua Grecia. Madrid, Síntesis, 2018.

Garcia SÁnchez, M. - Gleba, M. (EDS.): Vetus textrinum. Textiles in the ancient world. Studies in honour of Carmen Alfaro Giner. Barcelona, Universidad de Barcelona, 2018.

Letamendia Belzunce, F.: Cultura política en Occidente. Arte, religión y ciencia. Tomo I. Antigüedad (Grecia, Roma, Cristianismo y Antigüedad Tardía, Edad Media). Bilbao, Universidad del País Vasco, 2018.

Marín Martínez, A.P.: Los mercenarios en el Mediterráneo antiguo e Iberia (siglos V-III a.C.) Salamanca, Signifer, 2018.

Martín, T. R.: Pericles. Una biografía en su contexto. Traducción de G. Esteban. Madrid, Rialp, 2018.

MAYOR, A.: Fuego griego, flechas envenenadas y escorpiones. La guerra química y biológica en la Antigüedad. Madrid, Desperta Ferro, 2018.

Molina Marín, A.I.: Alejandro Magno (1916-2015). Un siglo de estudios sobre Macedonia antigua. Zaragoza, Pórtico, 2018. 
OBeR, J.: Demópolis. La democracia antes del liberalismo: teoría y práctica. traducción y notas de J. Cano Cuenca. Madrid, Casus Belli, 2018.

Pascual, J. - Antela-Bernández, B. - Gómez Castro, D. (eds.): Cambio y pervivencia: el mundo griego en el siglo IV a.C. Madrid, Universidad Autónoma de Madrid, 2018.

RoA, S.: Enemigos de Esparta. Barcelona, Ediciones B, 2018.

Scott, M.: Delfos. Historia del centro del mundo antiguo. Revisión científica de V. Ortega. Traducción de F. García Lorenzana. Barcelona, Ariel , 2018.

Tejera Orosa, R.: De la prehistoria al mundo antiguo: conocimiento social. Las Palmas de Gran Canaria, Ecca, 2018.

Zarzalejos Prieto, M - Guiral Pelegrín, C. - San Nicolás Pedraz, M.P.: Historia de la cultura material del mundo clásico. Madrid, Universidad Nacional de Educación a Distancia, 2018.

Zarzalejos Prieto, M - Guiral Pelegrín, C. - San Nicolás Pedraz, M.P.: Historia de la cultura material del mundo clásico. Addenda. Madrid, Universidad Nacional de Educación a Distancia, 2018.

\section{RELIGIÓN. MITOLOGÍA}

AA.VV.: El libro de la mitología. Madrid, Akal, 2018.

Alba, Y.: Sacerdotas. La mujer en las diferentes liturgias y religiones. Córdoba, Almuzara, 2018.

Álvarez soria, I.J.: "El santuario de Delos y la construcción de la identidad en el mar Egeo", Antesteria 7, 2018, 121-134.

Burkert, W.: Cultos mistéricos antiguos. Madrid, Trotta, 2018.

Cabrera Bonet, P.: "Orfeo en los Infiernos. Imágenes apulias del destino del alma”, 'Ilu 23, 2018, $31-56$

Durán Velasco, J.F.: Amazonas. Mujeres guerreras en la mitología. Córdoba, Almuzara, 2018.

Estévez Rodríguez, M.A.: ¿Mímesis o cosmogonía? Mitos grecolatinos y judeocristianos. Cubierta e ilustraciones de L. Estévez Alfonso. Almería, Círculo Rojo, 2018.

Febres-Cordero, L.: Prometeo cautivo. Madrid, Fundación CITAP, 2018.

Fernández Vega, P. A.: Bacanales. El mito, el sexo y la caza de brujas. Madrid, Siglo XXI, 2018.

González González, M.: Creencias y rituales funerarios. El Más Allá en la Grecia antigua. Madrid, Síntesis, 2018.

Hernández Castro, D.: "El temenos de Apolo y Aristeas en Metaponto. Una aproximación a la influencia de Delfos sobre la Magna Grecia", 'Ilu 23, 2018, 111-128.

JaÉn SÁnchez, M.: La cólera de Aquiles. Madrid, Gredos, 2018.

JAÉn SÁnchez, M.: Zeus conquista el Olimpo. Madrid, Gredos, 2018.

JaÉn Sánchez, M. - Moreno Cabrera, J.C.: Los viajes de Ulises. Madrid, Gredos, 2018.

Martos Montiel, J.F.: "La Homosexualidad Femenina en los Textos Astrológicos de la Antigüedad (1): El Carmen Astrologicum de Doroteo de Sidón", MHNH 17, 2017, 167-182.

MenÉndez Hernández, J.: Por deseo de Júpiter: la metamorfosis de la mitología griega en el siglo XXI. Prólogo de F. Sampedro Menéndez. Ilustraciones de A. Pardo. Madrid, Sial Pigmalión, 2018.

Perea Yébenes, S. - Tomás García. J. (eds.): Glyptós. Gemas y camafeos grecorromanos: Arte. Mitologías. Creencias. Madrid- Salamanca, Signifer, 2018.

Pérez Miranda, I.: "Padres terribles: engaño, incesto y antropofagia en la mitología griega", Las edades vulnerables 43-59.

Reyes BARRios, V.: "Anubis, el dios funerario: revisión de su papel desde Egipto hasta el mundo greco-romano", Antesteria 7, 2018, 77-90.

Rodríguez-Díaz, M. - Santana Henríquez, G.: "Los inicios de un debate interminable: la cuestión del origen de los Campos Elisios en la Antigüedad", CFCG 28, 2018, 267-280. 
SÁnchez Marcos, J.: La cólera de Aquiles. Mitología Gredos. Barcelona, RBA, 2018.

Sierra, J.: En busca de la edad de oro. Barcelona, Booket, 2018.

Souvirón, B.: El laberinto del Minotauro. Barcelona, RBA Libros, 2018.

Souvirón, B.: Los trabajos de Hércules. Barcelona, RBA Libros, 2018.

Souvirón, B.: Prometeo y el secreto del fuego. Mitología Gredos. Barcelona, RBA, 2018.

Stratiki, K.A.: "La mort violente de la figure héroïque", Religiones. (No) violencia y diálogo 51-76.

Torregrosa, D.: Del mito al laboratorio: la inspiración de la mitología en la ciencia. Palencia, Cálamo, 2018.

\section{CRISTIANISMO}

Bermejo Rubio, F.: La invención de Jesús de Nazaret. Historia, ficción, historiografía. Madrid, Siglo XXI, 2018.

Bermejo Rubio, F.: "El concepto de muerte vicaria en el mondo grecorromano y su influencia en la primera reflexión cristiana sobre la muerte de Jesús de Nazaret”, SPhV 20, 2018, 47-71.

Brotóns Merino, M.J.: "Los $\psi \varepsilon v \delta o \pi \rho o \varphi \tilde{\tau} \tau \alpha$ (falsos profetas) como mensajeros del Diablo en los textos del cristianismo primitivo", Los orígenes del cristianismo en la literatura, el arte y la filosofía II, 157-172.

Castro Couceiro, J.A.: "Símbolos del cristianismo primitivo en interpretacíón psicológica", Los orígenes del cristianismo en la literatura, el arte y la filosofía II, 241-254.

DE PAZ Amérigo, P.: "La crítica cristiana a la doctrina de la transmigración de las almas", Los orígenes del cristianismo en la literatura, el arte y la filosofía II, 97-116.

Giménez Delgado, J.V.: "La red viaria grecorromana y la difusión del cristianismo", Los orígenes del cristianismo en la literatura, el arte y la filosofía II, 81-96.

Goguel, M.: Judíos y romanos en la historia de la pasión. El problema histórico del arresto de Jesús. Estudio preliminar, traducción y epílogo de F. Bermejo Rubio. Salamanca, Signifer, 2018.

López Salvá, M.: "La plegaria en los Padres hesicastas y sus antecedentes", Los orígenes del cristianismo en la literatura, el arte y la filosofía II, 385-399.

Martín Hernández, R.: "El poder de las imágenes en la magia a partir del s. IV d.C. Las representaciones de Jesús", Los orígenes del cristianismo en la literatura, el arte y la filosofía II, 255-268.

Martínez Gázquez, J. - Ferrero Hernández, C.: "Ramón Llul y la fundación de un Studium Arabicum, Tartaricum et Graecum en París y otras universidades", AFAM 8, 2018, 539-550.

Piñero, A.: Aproximación a Jesús histórico. Madrid, Trotta, 2018.

Piñero, A.: Orígenes del Cristianismo, antecedentes y primeros pasos. Barcelona, Herder, 2018.

Rodríguez Carmona, A.: El cristianismo naciente. El cristianismo emergente a la luz de los Hechos de los Apóstoles. Madrid, Biblioteca de Autores Cristianos, 2018.

SÁnChez de Mayo, P.: "La alimentación en los orígenes del cristianismo: el caso de la abstinencia alimenticia en los primeros monjes y ascetas", Los orígenes del cristianismo en la literatura, el arte y la filosofía II, 211-224.

Sol Jiménez, E.: "La espiritualidad como no-violencia: los cristianos gnósticos", Religiones. (No) violencia y diálogo 165-182.

Sol JimÉnEZ, E.: "Diferencias rituales en el gnosticismo: la investidura y la cámara nupcial”, Los orígenes del cristianismo en la literatura, el arte y la filosofía II, 173-192.

\section{FILOSOFÍA. CIENCIA}

Ávila Crespo, R.: Las pasiones trágicas. Tragedia y filosofía de la vida. Madrid, Trotta, 2018. 
Aviñó McChesney, A.: "Ariadna habita los pliegues. Foucault y la ontología de sí mismo", Convergencias y divergencias 47-78.

FERnÁNDEZ-Figares, M.D.: Los primeros filósofos. Madrid, Editorial N.A., 2018.

Gómez PÉrez, R.: De Homero a Kafka, 75 clásicos para una geografía del alma. Madrid, Rialp, 2018.

Martínez, F.J.: "Grecia como ideal en el marco de la globalización”, Convergencias y divergencias 111-136.

Mas Torres, S.: Epicuro, epicúreos y el epicureísmo en Roma. Madrid, UNED, 2018.

Mejía Rivera, O.: Medicina antigua. De Homero a la peste negra. Madrid, Punto de Vista, 2018.

Mercadé Serra, M.: La Concepció filosófica de la vida domèstica. Fonamentació histórica en la filosofía grega. Tesis Doctoral, Universidad de las Illes Balears, 2018.

NúÑ̃z García, A.: "Cosmopolitismo: un concepto de actualidad (Algunas notas sobre cinismo e estoicismo antiguo)", Convergencias y divergencias 79-110.

Pigliucci, P.: Cómo ser un estoico. Utilizar la filosofía antigua para vivir una vida moderna. Barcelona, Ariel, 2018.

Pla i Carrera, J.: Història de la Matemàtica. Grècia IIa (Els Elements d' Euclides, Llibres I, II, III, IV, Vi VI). Resultats, textos i contextos. Barcelona, Institut d'Estudis Catalans, 2018.

Ripoll Miralda, J.: Grec mèdic. Guia per identificar termes. Barcelona, Publicacions de l'Abadia de Montserrat, 2018.

Strauss, L.: El gusto de Jenofonte. Una introducción a la filosofía. Estudio preliminar, notas y traducción de A. Lastra y A. Fernández Díez. Madrid, Biblioteca Nueva, 2018.

Vives Vallés, M.A. - Mañé Seró, M.C.: El inicio de la medicina animal. Del Neolítico a la cultura grecorromana. Cáceres, Universidad de Extremadura, 2018.

Zellini, P.: Número y logos. Traducción de J. Díaz de Atauri, Barcelona, Acantilado, 2018.

ZubIRI, X.: Introduccion a la filosofía de los griegos. Lecciones en Barcelona, Ameixenda y Madrid (1941-1943). Madrid, Alianza, 2018.

\section{PERVIVENCIA. HUMANISMO. HISTORIA DE LA FILOLOGÍA}

AA.VV.: Sobre El Nacimiento de la Tragedia (= Estudios Nietzsche, Revista de la Sociedad Española de Estudios sobre Friedrich Nietzsche 17). Madrid, Trotta, 2017.

Agudo Villanueva, M.: Atenas. El lejano eco de las piedras. Almería, Confluencias, Almería, 2018.

Amestoy Eguiguren, J.I.L.: Claves de escritura dramática contemporánea a través de la tragedia griega. Tesis Doctoral. Madrid, Universidad Complutense de Madrid, 2018.

Antela Bernárdez, I.B.: "La Antigüedad en la versión española de la Propyläen Weltgeschichte (1986)", Pyrenae 49(2), 2018, 87-100.

Aponte-Olivieri, S.: "Intertextualidad onomástica en La pasión según Antígona Pérez de Luis Rafael Sánchez", Ecos y resplandores helenos 187-202.

BALDwin, O.: "¿Qué hay de heroico en todo esto? La Ilíada de La Joven Compañía”, Tycho 6, 2018, 7-20.

BARBIERI, L.: "La matière troyenne en Italie et en italien : le Roman de Troie, des traductions anonymes à Boccace", Troianalexandrina 18, 2018, 151-165.

Baumgartner, E.: "La Legende de Troie en Europe au Moyen Âge”, Troianalexandrina 18, 2018, 27-34.

BÉRCHEZ CASTAÑo, E.: "Escila y Caribdis, criaturas mitológicas de Homero en los proverbios y expresiones latinas", Paremia 27, 2018, 105-116.

Blain, C. - Sfar, J.: Sócrates. Madrid, Fulgencio Pimentel, 2018. 
Bognolo, A.: “'Los libros de caballerías, de quien nunca se acordó Aristóteles': Cervantes, la Poética de Aristóteles y la crítica de la ficción”, Ecos y resplandores helenos 427-448.

Borrego Gutiérrez, E.: "Del mito a la escena. Una Fábula de Dafne de finales del siglo XVI en las Descalzas Reales", AM 39, 2016-2017, 321-334.

Bravo de Laguna Romero, F.J.: "Medeas en la frontera. La tradición clásica en tres piezas teatrales latinoamericanas", $A E F$ 4I, 2018, 43-60.

Campbell, Y.: "Presencia platónica en Examen de maridos de Juan Ruiz de Alarcón", Ecos y resplandores helenos 291-308.

Canfora, L.: "Los griegos y los demás", Métodos y técnicas en Ciencias de la Antigüedad, 75-82.

Cantarero de Salazar, A.: "Sobre el filósofo hispalense Sebastián Fox Morcillo: de comentarista (Timeo, Fedón y República) a imitador de Platón”, Ecos y resplandores helenos 575-604.

Carbó, F.: "Dos reflexos de Joan Salvat-Papasseit en el metro de París", L'empremta del mite 11-30.

Carrasco, M. - Elvira Barba, M.Á.: Los mitos en el Museo del Prado. Madrid, Guillermo Escolar, 2018.

Carvallo Carvallo, B.: Lecturas del mito de Electra. Una lectura com parada entre las versiones del mito en Eurípides y en Jean Paul Sartre. Madrid, Académica Española, 2018.

Castro Jiménez, M.D.: "Lecturas de la metamorfosis de Dafne en la poesía española contemporánea", Myrtia 33, 2018, 375-404.

Cereceda Oyón, G.: "La tradición clásica en Volver al mundo", Faventia 28, 2016, 95-103.

ClerCX, S.G.: "Forgotten Connections: implicit and explicit Uses of Classical Scholarship in the Comparisons of Sir William Jones's On the Gods of Greece, Italy, and India (1784)", Myrtia 33, 2018, 295-319.

Coenen, E.: "Diógenes y Alejandro Magno en las tablas barrocas", Ecos y resplandores helenos 261276.

Cohen-Skalli, A. - Marcotte, D.: "Guarino Veronese, annotateur de Strabon. Observations sur le Bodleianus Canonici Class. Lat. 301", De nuevo sobre Estrabón 137-159.

CRISTÓBAL LóPEZ, V.: "De la épica grecolatina a la épica culta española", Visiones y aspectos puntuales de la épica grecorromana 247-320.

Deriu, M.: "Dal mito al cinema attraverso il fumetto: le Amazzoni, Wonder Woman e la norma delle identità di genere", İtaca 34, 2018, 173-202.

ERasmo de Rotterdam: Diálogo de la PRONUNCIACIÓN CORRECTA DEL LATín Y EL GRIEGo. Edición y traducción de M. Sanz Ledesma. Introducción de M. Sanz Ledesma y E. Sánchez Salor. Cáceres, Universidad de Extremadura, 2018.

Escobar Chico, Á.: "Observaciones sobre la uetus translatio del De insomniis aristotélico y su reelaboración por Guillermo de Moerbeke”, Emerita 86, 2018, 51-70.

Esteban Santos, A.: “'Resplandores’ helenos en el Conde de Villamediana: pretender alcanzar el sol", Ecos y resplandores helenos 131-160.

Esteve, P.J.: Nicandri Theriaca. Traducción latina en verso (1552). Introducción, edición crítica, traducción y notas de M.T. Santamaría Hernández. Cuenca, Universidad de Castilla-La Mancha, 2018.

Faivre D'Arcier, L.: “Sur les traces de Darès le Phrygien dans l'Occident médiéval”, Troianalexandrina 18, 2018, 37-56.

Fernández Marcos, N.: "La Biblia griega de Alejandría y nuestra cultura occidental”, Los orígenes del cristianismo en la literatura, el arte y la filosofía II, 15-24.

Franco Llopis, B. - Molina Martín, Á. - Vigara Zafra, J.A.: Imágenes de la tradición clásica y cristiana. Una aproximación desde la iconografía. Madrid, Editorial Universitaria Ramón Areces -UNED, 2018. 
FraschinI, A.E.: "Leopoldo Marechal y los clásicos griegos. Reescrituras e imitaciones", Ecos y resplandores helenos 493-510.

Frías UrReA, R.: "Mito y logos: Humberto Giannini y el carácter narrativo de la existencia humana", Ecos y resplandores helenos 483-492.

Galindo Esparza, A.: "Traducciones femeninas de Homero: un microrrelato y sus antecedentes clásicos", EClás.153, 2018, 105-124.

Gallé Cejudo, R.J.: "Francisco Sarmiento Iunior (I): los epigramas laudatorios griegos al frente del De Redditibus de Francisco Sarmiento Senior", Cal.Ren.18, 2017, 51-70.

Gallé Cejudo, R.J.: "Nuevas consideraciones en torno a los Epigramas helenísticos de Gabriel Celaya", Ecos y resplandores helenos 79-92.

García Jurado, F.: "Lecturas españolas de la Historia de la literatura griega de Karl Otfried Müller: Santiago Usoz (1860) y Alfredo Adolfo Camús (1889)", Ecos y resplandores helenos 511-534.

Gatsioufa, P. - Valverde Abril, J.J.: "Habent sua fata libelli: Catálogo descriptivo de las ediciones de los Apophthegmata de Conradus Lycosthenes", Nardus et myrto plexae coronae 145-178.

Gerbino, L.: La mediación educativa de Juan Lluís Vives. Un estudio comparativo de las relaciones entre humanismo y filosofía desde la segunda mitad del siglo XV hasta la primera mitad del siglo XVI en Europa. Tesis doctoral, Universidad de Alicante, 2018.

GianotTi, G.F.: "Storia di un antifascista siciliano, professore di lingue classiche: Carmelo Salanitro

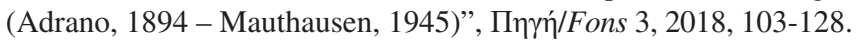

GILABERT BARBerà, P.: El vessant seriós i tràgic de Woody Allen: ètica I vitalisme d'inspiració grega. Barcelona, Universitat de Barcelona, 2018.

Gómez Luque, J.A.: El tópico literario de la travesía del amor: de la literatura clásica a la poesía española de los Siglos de Oro. Tesis Doctoral. Córdoba, Universidad, 2018.

González Delgado, R.: "Los Pelópidas de Jorge Llopis y la parodia de la tragedia griega”, CFCG 28, 2018, 281-304.

GonZÁlez Vaquerizo, H.: "Libertad o muerte. Una Ilíada cretense (y modernista)”, Phílos hetaîros 265-272,

GraÑA, M.C.: "Ecos de la cultura grecolatina en dos poemas largos de Gabriela Mistral: Clitemnestra y Casandra", Ecos y resplandores helenos 93-112.

Hernández Muñoz, F.G.: "En el quinto centenario de la muerte de Cisneros: breve semblanza de Demetrio Ducas, primer catedrático de griego de la Complutense", CFCG 28, 2018, 305-312.

HERnÁNDEZ Rodríguez, R.: "Faunos en los trópicos: modernismo y virilidad", Ecos y resplandores helenos 113-130.

Hernando Morata, I.: "El laberinto de Creta en el teatro español del siglo de oro", Ecos y resplandores helenos 241-260.

IвÁÑ̃z Chacón, Á.: "Sobre Las cincuenta fábulas de Conón, traducidas por Cándido María Trigueros (1768)", EClás.154, 2018, 93-108.

Iglesias Feijoo, L.: "El mito de Ulises en Torrente Ballester y Buero Vallejo", Ecos y resplandores helenos 203-230.

Jucknies, R.: "Icelandic Dares, Swedish Guido. The Reception of the Trojan Matter in the North", Troianalexandrina 18, 2018, 83-99.

Kebadze, N.: "El acervo platónico en Memorias de Leticia Valle (1945) de Rosa Chacel”, Ecos y resplandores helenos 383-392.

Kellner, B.: "Konrad of Würzburg's German Version of the Trojan War: a Combination and Transformation of Sources", Troianalexandrina 18, 2018, 217-231.

LapeÑa Marchena, Ó.: "La Antigüedad ya estaba allí: la dualidad construcción / destrucción en el cine sobre el Mundo Antiguo", Habis 49, 2018, 271-290. 
Lesage GÁrRIga, L.: "Aldinas anotadas: una puesta al día de la contribución de los humanistas a través del estudio de De facie", CFCG 28, 2018, 243-265.

López Calahorro, I.: "La recepción del legado de Pausanias en el paisaje argelino de Albert Camus: de Chateaubriand a James G. Frazer", Myrtia 33, 2018, 321-341.

López-Pampló Rius, G.: "El Prometeu irònic de Josep Carner. Estudi de l'article Prometeu i els llumins", L'empremta del mite 31-52.

López Recio, V.: "Grecia en el poeta Andrés Sánchez Robayna: un diálogo entre las imágenes de la historia y la realidad más inmediata", Ecos y resplandores helenos 47-66.

Lorenzi, C.: "A Source of the Aventuroso ciciliano (14th century): the Reuse of Filippo Ceffi's Florentine Translation of the Historia destructionis Troiae", Troianalexandrina 18, 2018, 167-180.

Machado Alejandro, C.: "La poesía de Circe Maia y su diálogo con la filosofía griega", Ecos y resplandores helenos 67-78.

Maestre-Brotons, A.: "La dona fatal en L'adolescent, d'Alfons Maseras (1909)", L'empremta del mite 53-78.

Malé i Pegueroles, J.: "Una odissea transtextual: els Ulisses de Carles Riba”, L'empremta del mite 79-110.

Martín Rodríguez, M.: "Civilised Men, Monstrous Cyclopes, and Troglodytes in Modern Imaginary Voyages Set in Classical Antiquity (Schwob, Moravia, Bene区, Borges)", FI 29, 2018, 91-110.

Mavrelos, N.: "El Criticón como reflejo del mito platónico de la caverna en el mundo cristiano de la modernidad temprana: intertextualidad e ideología”, Ecos y resplandores helenos 393-408.

MedDA, E.: "Odisseo a Itaca: il monologo di Od. XIII 187-221 fra critica analitica e poetica dell'ironia (con una nota su Il Ritorno di Giovanni Pascoli)", İtaca 34, 2018, 7-29.

Melo, A.M.M.: "Homero e Virgílio, um agon memorável na Poética de J.C. Escalígero: palavras introdutórias", Nardus et myrto plexae coronae 243-258.

Morenilla Talens, C.: "Hécuba, mater dolorosa en Roís de Corella, Jaime de Huete y el romancero popular", Cal.Ren.18, 2017, 131-146.

Moya Del BaÑo, F.: "Homero en Quevedo. Notas de lectura", Ecos y resplandores helenos 161-186.

Nixey, C.: La edad de la penumbra. Cómo el cristianismo destruyó el mundo clásico. Madrid, Taurus, 2018.

OpRISA, V.: "La paideia antigua y la adaptación de los coloquios escolares en México: Francisco Cervantes de Salazar", Ecos y resplandores helenos 463-482.

Ortega Castro, M.: "Amistad y aristotelismo en la Francia del siglo XVI: las versiones latinas de la Política de Dionisio Lambino y Pierre de la Ramée", FI 29, 2018, 195-210.

Paleologos, K.: "La mitología griega en la minificción hispana: intertextualidad y deconstrucción", Ecos y resplandores helenos 361-382.

Pastor Botella, L.: "Euclides en España (siglos XV y XVI)", Tempus 43, 2018, 7-12.

Peláez Marqués, J.M.: Vigencia de los modelos de liderazgo del héroe clásico. Tesis doctoral. Madrid, Universidad Autónoma de Madrid, 2018.

Pérez Carrillo, C.: "La traducción de Poliziano del Himno al baño de Palas de Calímaco", Opera selecta $113-123$.

Pérez Gómez, L.: "Del mito de Medea al `Síndrome de Medea’”, FI 29, 2018, 211-238.

Peyrard, S.: "Notes sur l'Iliade de Simon Chèvre d'Or", Troianalexandrina 18, 2018, 129-149.

Pimentel, M.C.: "Penélopes e Fedras no nosso tempo", Cal.Ren.18, 2017, 147-170.

Pociña LóPeZ, A.J.: "Algunos ejemplos de orestíadas en el Occidente de la Península Ibérica”, Cal. Ren.18, 2017, 193-208.

Pozuelo Calero, B.: "Neoestoicismo en el humanismo sevillano de la segunda mitad del siglo XVI", Cal.Ren.18, 2017, 209-224.

PunZI, A.: "Matière Troyenne et exégèse dantesque", Troianalexandrina 18, 2018, 57-81. 
Quintana, L.: "Níobe en tramvia, de Joan Maragall: el mite i l'infraordinari”, L'empremta del mite 111-123.

Rábade Navarro, M.Á.: "Homero en Liquidación final de Petros Márkaris: la búsqueda del efecto equivalente en traducción como pista en una novela policiaca", Cal.Ren.18, 2017, 225-236.

Redondo Pérez, G.: "Calumnia y Vitarum auctio: dos obras de Luciano traducidas por Sancho Bravo de Lagunas", Ecos y resplandores helenos 409-426.

Ritsos, Y.: Agamenón. Madrid, Acantilado, 2018.

Rivero, C.: "El retorno de Ulises tras la II guerra mundial", Ecos y resplandores helenos 231-240.

Rodríguez Alfageme, I.: "Fuentes para una traducción: Laguna, Tragopodagra", Cal.Ren.18, 2017, 245-268.

Rodríguez Blanco, M.E.: "Penélope vuelve a tejer”, Phílos hetaîros 281 -292.

Rodríguez López-VÁzQuez, A.: "Ulises, Jasón, Eneas y el mito de Don Juan: la ‘hipótesis grecolatina' y la obra de Claramonte", Ecos y resplandores helenos 277-290.

Roselló, R.X.: "Al voltant dels `Cicles de Fedra' de Llorenç Villalonga", L'empremta del mite 125159.

Ruiz PéRez, P.: "Diógenes Laercio y las biografías literarias en la Edad Moderna”, Ecos y resplandores helenos 605- 627.

Russell, J.M.: De Platón a Winnie the Pooh. Madrid, Alianza, 2018.

SÁnchez Bellido, S.: "El tópico de la laus urbis y los Coloquios de Baltasar de Collazos: tradición, sátira y crítica social", Ecos y resplandores helenos 449-462.

Sánchez Manzano, M.A.: El escepticismo humanista de Francisco Sánchez. Madrid, Dykinson, 2018.

Sanz Julián, M.: "Les pages de titre des éditions imprimées de la Crónica Troyana castillane (de 1490 à 1587)", Troianalexandrina 18, 2018, 181-215.

Szerwiniack, O.: "Le mythe de Troie en Irlande au Moyen Âge : Togail Troí et ses recensions", Troianalexandrina 18, 2018, 101-125.

Simbor Roig, V.: “Josafat: Mite, llegenda i recreació hipertextual”, L'empremta del mite 161-185.

Terol Plá, G.: "La recreación trágica como reflejo y crítica de la realidad en Tiresias, aunque ciego (2000)", AM-EL 44-45, 20 I 8, 85-105.

Terol Plá, G.: "Transgresión y humanización en Electra-Babel de Lourdes Ortiz", EH 40, 2018, 353370.

Torregrosa, D.: Del mito al laboratorio: la inspiración de la mitología en la ciencia. Palencia, Cálamo, 2018.

Trueba Mira, V.: "Invertir el platonismo en la poesía española contemporánea", Ecos y resplandores helenos 23-46.

Valenzuela Matus, C.: "Aristóteles en el Nuevo Mundo. La zona tórrida en las historias naturales jesuitas (siglos XVI-XVII)", 557-574.

VAlverde Abril, J.J.: "Los Apophthegmata de Conradus Lycosthenes o las vicisitudes de la sabiduría humanística ", Nardus et myrto plexae coronae 419-469.

Velasco López, M.H.: "La trilogía de las metamorfosis de A. Camilleri y los mitos clásicos", Myrtia 33, 2018, 343-374.

VelázQuez Velázquez, R.: "La reescritura de los mitos clásicos en el microrrelato español del siglo XXI", Ecos y resplandores helenos 333-360.

Xouplidis, P.: "Los gatos literarios: de la fábula de Esopo a dos cuentos de Luis Sepúlveda", Ecos y resplandores helenos 309-332.

ZoppI, F.: "Evolución del concepto aristotélico de ‘admiración' en los tratados poéticos de los siglos XVI y XVII", Ecos y resplandores helenos 535-556. 


\section{DICCIONARIOS. REPERTORIOS. OTROS INSTRUMENTOS}

Bergua Cavero, J.: "Etimologías griegas en el diccionario de Corominas y en el Nuevo diccionario histórico del español: observaciones críticas sobre objetivos y métodos en dos obras de referencia", Minerva 31, 2018, 249-261.

RAmírez-SÁNCHez, M.: "Las Ciencias de la Antigüedad en España en la encrucijada: retos y oportunidades en la sociedad digital", Métodos y técnicas en Ciencias de la Antigüedad 13-36.

Ripoll Miralda, J.: Grec mèdic. Guia per identificar termes. Barcelona, Publicacions de l'Abadia de Montserrat, 2018.

Rodríguez Somolinos, H.: "Publicaciones sobre Filología griega en España (2017)”, Epos 34, 2018, 261-302.

Ruiz Vila, J.M. (COORD.): “Novedades bibliográficas españolas”, Tempus 43, 2018, 93-132.

Ruiz Vila, J.M. (COORD.): “Novedades bibliográficas españolas”, Tempus 44, 2018, 99-139.

\section{DIDÁCTICA}

Camino, M.E. - Moulins, A.: "Medea en la pampa argentina", Thamyris 9, 2018, 257-274.

Carbonell Martínez, S. - Garrido Castelló, M.: "Las Helénicas de Jenofonte: una selectividad diferente es posible", Thamyris 9, 2018, 155-172.

DuRÁn MAÑAs, M. (COORD.): El mundo clásico a través del cómic. Creatividad e innovación para una enseñanza literaria bilingüe e interdisciplinar. Valencia, Educàlia, 2018.

García Peña, I. - García Castillo, P.: Materiales didácticos de Historia de la Filosofía antigua. Salamanca, Universidad, 2018.

GAY SÁnchez, F.: Supervivencia de la cultura clásica. El latín y el griego en los IES. Huesca, Scribo, 2018.

Gázquez Rodríguez, P.: Los dioses del Olimpo. Ilustraciones de O. Ayén Hernández y otros. Lorca, Tres Columnas, 2018.

Gheerbrant, X. - Zeng, Y.: "A new Chinese-language textbook of ancient Greek with a historical outline of teaching Greek and Latin in China", Thamyris 9, 2018, 173-212.

Gomariz Sánchez, S.: Cuadrando mitos. Un proyecto de innovación educativa. Murcia, Diego Marín, 2018.

Husillos García, M.L.: "Aproximación a la cerámica griega a través de las portadas de obras literarias", Thamyris 9, 2018, 275-318.

IANNELla, A.: "Digital authentic learning: introdurre alla tone analysis per favorire un pensiero critico digitale", Thamyris 9, 2018, 319-336.

Ibáñez Chacón, Á.: Crestomatía de autores griegos anotados I. Prosa. Madrid, Áurea Clásicos, 2018.

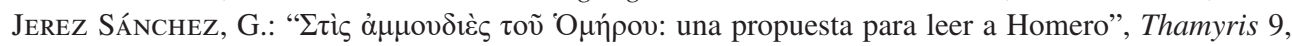
2018, 213-228.

Molina Tortosa, L.: "La mujer en Grecia: un modelo de unidad didáctica para $\triangle \mathrm{IA} \Lambda$ ОГО Thamyris 9, 2018, 229-238.

Navarrete Orcera, A.R.: Mitología para jóvenes. Málaga, Anejos de Thamyris, 2018.

Navarro González, J.L. - Rodríguez Jiménez, J.M.: Griego. Evaluación de Bachillerato 2017 Madrid, Anaya, 2018.

Platón: Apología de Sócrates. Cómic. Edición en español de E. Manzanares Sabater y E. Navarro Galán. Madrid, Áurea Clásicos, 2018.

Robles Rey, E.: "Maior amor matris est", Thamyris 9, 2018, 337-350.

Rodríguez Alfageme, I.: Gramática griega. Madrid, Ediciones Complutense, 2018. 
Ros, A.: Una odisea alucinante. Libro didáctico sobre la historia de la filosofía y su contexto histórico-cultural en la Grecia Antigua. Almería, Círculo Rojo, 2018.

RugGiero, G.: "Il ruolo del lessico nell'integrazione didattica tra lingua e grammatica", Thamyris 9, 2018, 239-256. 
